\title{
A magyar bankrendszer tulajdonosi struktúrájának átalakulása
}

A cikk a szakirodalmi áttekintést követően az elmúlt három évtized magyar banktörténelmén keresztül vizsgálja meg, hogy milyen szerepe volt a bankrendszerek tulajdonosi struktúrájának a válság kialakulásában, illetve a válság negatív hatásainak leküzdésében. Az 1988-ban létrehozott - többségi állami, illetve szük belföldi tulajdonosi háttérrel jellemezhető - magyar bankrendszer összerogyott az 1990-es transzformációs válságának súlya alatt, viszont az ezredfordulón kialakult, többségi külföldi tulajdonnal jellemezhető struktúra ellenállónak bizonyult a 2008-as válság idején. A jelenlegi, az állam erőteljes szerepvállalásával kialakulóban lévő új banktulajdonosi szerkezet - amelyben a külföldi befektetők kiszorulnak, s előnyt élveznek a hazai szük tulajdonosi hátterü bankok - nem feltétlenül erösíti a bankrendszer válsággal szembeni ellenálló képességét. A struktúraváltás mellett felhozott érvek az irodalom és a banktörténelem fényében nem tünnek megalapozottnak.* Journal of Economic Literature (JEL) kód: F21, F23, F65, G01, G21, G28.

A bankrendszerek strukturális jellemzői hatással vannak a szektor müködésére, hatékonyságára, stabilitására, ellenálló képességére. Olyan bankrendszeri struktúra nem létezik, amely minden szempont szerint ideális. Az egyszerre legyen „versengö, növekvő, biztonságos, jövedelmező, alacsony felárral dolgozó, hatékony” követelmények egymást oltják ki, e szempontok között átváltás van, nem biztos, hogy a válságnak leginkább ellenálló struktúra a leginkább hatékony vagy a legjövedelmezőbb (Liikanen [2012]).

\footnotetext{
* A szerző 2007-2013 között a Magyar Nemzeti Bank pénzügyi stabilitásért felelös alelnöke volt. A tanulmányban kifejtettek kizárólag a szerző véleményét tükrözik. A dolgozat korábbi változatához tett értékes megjegyzéseiért és a dolgozat elkészültéhez nyújtott segítségéért ezúton mondok köszönetet Banai Ádámnak, Kerényi Ádámnak, Kornai Jánosnak, Magyar Bálintnak, Mérö Katalinnak, Mihályi Péternek, Móra Mária Tündének, Nagy Dánielnek, Simonovits Andrásnak, Vágó Nikolettnek, Várhegyi Évának, Voszka Évának, az MTA KTI-ben február 4-én és a Pénzügykutató Intézetben március 23-án rendezett vita hozzászólóinak, valamint a dolgozat két anonim lektorának.
}

Király Júlia, az International Business School Budapest tanára, az MTA KRTK külső munkatársa. A kézirat első változata 2016. január 9-én érkezett szerkesztőségünkbe.

DOI: http://dx.doi.org/10.18414/KSZ.2016.7-8.725 
Nem lehet egyetlen jó struktúrát kiemelni, egymással versenyzö megoldások közül kell az adott korszaknak és az adott gazdaságnak leginkább megfelelőt kiválasztani. Ez a bankrendszeri struktúra minden elemére (intézményi, tulajdonosi, méretbeli, tevékenységi összetétel) egyaránt igaz. A bankrendszer egy magas belépési korlátokkal védett, sürű szabályozási hálóval körülvett organizmus, amelynek alakulása, alakítása a mindenkori kormány gazdaságpolitikai irányát, értékválasztását is tükrözi. Kialakulása nem véletlenszerü, s egy-egy irányváltást általában szakmai viták, hatástanulmányok, empirikus elemzések sokasága szokott megelőzni.

A tanulmányban a bankrendszeri struktúrák fő kérdései közül a tulajdonosi struktúrával kapcsolatosakat emeljük ki. A különböző tulajdonosi struktúrákat különféle szempontok alapján szokás megítélni: a rendszer hatékonysága, a pénzügyi közvetítés költségei, a jövedelmezőség, a kockázatok mértéke, a versenyképesség és a verseny alakulása, a termékválaszték bővülése és a fogyasztó kényelme, a fogyasztóvédelem jellemzői, a pénzügyi közvetítés költségeinek alakulása, innovativitás (új, hatékony technológiák bevezetése), a gazdasági növekedés támogatása stb. A pénzügyi válságot követően kiemelten fontos vizsgálati szempont lett a különböző tulajdonú bankok válságot megelöző, a válság alatti és a válságot követő években megfigyelhetö üzletpolitikája, a válsággal szembeni ellenálló képessége, illetve az esetleges szanálás társadalmi költsége. Elsősorban ebből a szempontból hasonlítjuk össze a különböző tulajdonosi hátterű bankokat. A tulajdonosi struktúrákat a következő négy metszetben vizsgáljuk:

a) állami versus magántulajdonú bankok;

b) belföldi versus külföldi tulajdonú bankok;

c) egy különleges eset: közösségi tulajdonú bankok;

d) belföldi, szük tulajdonosi hátterü bankok.

Minden válságot követően a tulajdonosi struktúra az érdeklődés középpontjába kerül, hiszen az „mindig rendkívüli helyzetekben - mint a háború vagy széles területekre kiterjedő gazdasági válság idején - lendült mozgásba, mégpedig politikai indíttatásból, politikai jellegü döntésekkel és végrehajtással” (Voszka [2015b] 719. o.). Magyarországon a válság utáni átalakítás szintén alapvetően politikai indíttatású volt, ennek során azonban fájóan hiányzott a hatástanulmányok, viták, elemzések sokasága, ami Kornai János megállapítása szerint a korszak jellegzetessége (Kornai [2015]). A tulajdonosi szerkezet átalakításának alátámasztására felhozott érvek többsége - mint ezt a tanulmányban látni fogjuk - tényszerüen cáfolható. A politika által megfogalmazott üzenetek után azonban nagyon valós cselekvési program, határozott, a bankrendszeri struktúrát döntően módosító lépések sorozata következett

A tanulmányban áttekintjük az irodalom legfontosabb megállapításait, ezeket elsősorban a magyar, illetve a régióbeli banktörténelemből vett esettanulmányokkal támasztjuk alá. A hazai banktörténelem elmúlt 30 évének tulajdonosi struktúráját jellemző tendenciákat egyszerű megközelítésben a mérlegfőösszeg-alapú piaci részesedés változásával jellemezzük (a bankok összesített mérlegföösszegét tekintetjük a teljes bankpiacnak). Az egyedi bankok mérlegföösszegének 2003 elötti adatforrása a Magyar Pénzügyi Almanach címü évkönyvsorozat, 2003-tól pedig 
az elektronikusan is elérhető Aranykönyv-sorozat. ${ }^{1}$ Az irodalom föáramával összhangban a bankrendszeri struktúra elemzésekor nem vettük figyelembe az olyan speciális célú - és ezért speciális szabályozás (általában derogáció) alá tartozó intézményeket, mint amilyenek a fejlesztési bankok (MFB), az állami export-import kedvezményeket közvetítő intézmények (Exim Bank) és az elszámolóházak (Keler). Bankcsoportok esetében nem konszolidáltunk: a csoporthoz tartozó valamennyi magyarországi bank mérlegföösszegét hozzáadtuk az anyabankéhoz.

A bankokat a szakirodalommal összhangban mindig a többségi tulajdonos jellege alapján soroltuk be, feltételezve, hogy a többségi tulajdonos jellege határozza meg egy bank üzletpolitikáját, kockázatvállalását, hatékonyságát, azaz nem lehet egy bank 20 százalékban óvatos, 35 százalékban okos kockázatvállaló és 45 százalékban pedig „szerencselovag”, a bank stratégiáját a többségi tulajdon jellege határozza meg. A tanulmány ezen túlmenően nem tartalmaz ennél mélyebb, esetlegesen több országra kiterjedő empirikus (ökonometriai) elemzést, azonban így is lehetővé válik bizonyos tendenciák azonosítása. Mindenképp további kutatás szükséges ahhoz, hogy a jelenlegi változások által létrehozott új tulajdonosi struktúráról megalapozott értékítéletet mondhassunk.

A magyar banki piacon végbement strukturális változások jól illeszkednek a Kornai [2015] által $U$ kanyarként jellemzett „új gazdaságpolitika” többi lépéséhez. A létrejött új struktúra több vonásában is gyengébb tőkehátteret és így gyengébb ellenálló képességet jelez elöre, mint a válság előtti.

A tanulmány szerkezete követi a már említett négy metszet szerinti megközelítést: elöször az állami versus magántulajdont, majd a belföldi versus külföldi tulajdont vizsgáljuk. Ezután kitérünk egy különleges tulajdonformára, a közösségi tulajdonra, majd a szűk tulajdonosi hátterü bankokra. Végül összefoglaljuk a tanulmány főbb megállapításait.

\section{Állami versus magántulajdonú bankok}

Elöször az állami versus magántulajdon kérdésével foglalkozunk. Az állami tulajdon melletti érvelés a magasabb növekedési lehetőséget és a szociális szempontok állami tulajdonos általi előtérbe helyezését hangsúlyozza. Az ellenkező nézet az állami tulajdon immanens vállalatirányítási problémáit emeli ki: a rossz kontrollmechanizmusokat, a szükségszerüen fellépő korrupciót és a hibás (újabb piaci kudarcokhoz vezetö) magatartást mutatja be. Az empirikus tanulmányok alapján a privatizáció jobban hozzájárult a hatékonyság és az ellenálló képesség növekedéséhez, semmint gátolta azt. A kilencvenes évek magyar banktörténelme is inkább azt igazolja, hogy állami tulajdon mellett romlik a müködési hatékonyság, nő a törékenység, teret kap a

\footnotetext{
${ }^{1}$ A szerző 1989-től építi a Magyar Pénzügyi Almanach segítségével az egyedi bankok mérlegadatait tartalmazó adatbázisát. Ezúton mondok köszönetet az almanach szerkesztőinek és kiadójának (TAS11 Kiadó). 2003-tól a PSZÁF és utódintézménye, az MNB elektronikusan jelenteti meg az Aranykönyvet: a Tájékoztató a felügyelt intézmények egyedi adatairól című kiadványát (2003-2015, https://www. $\mathrm{mnb}$.hu/felugyelet/idosorok/v-aranykonyv).
} 
korrupció. A válság során a világban az állami bankok nem voltak ellenállóbbak, mint a magánbankok, sőt nagyobb mértékben szorultak szanálásra. A megrendült magánbankokban az állam szanálási céllal szerzett tulajdonrészt, tartós, üzleti célú állami tulajdon nem jött létre. A szakirodalomban nincsen példa a jelenlegi magyar tulajdonosi struktúra kialakítását jellemző tendenciára, az állam üzleti célú tulajdonszerzésére. E megállapításokat részletezzük a következőkben.

Azt, hogy az „államosítás” vagy a „privatizálás” kap prioritást a bankszektorban - miként a gazdaság többi szektorában is -, politikai érvek döntik el, ez mindig politikai gazdaságtani, sohasem tisztán gazdasági kérdés. Általában a döntés összekapcsolódik valamilyen nagyobb horderejü társadalmi/politikai változással, és általában az éppen fennálló problémák általános megoldását várják hol a privatizációtól, hol az államosítástól.

Az állami tulajdonlás hagyományos érvei (Voszka [2015a], [2015b]), amelyek fokozottan érvényesnek tünnek a bankrendszerekre, a következők: a piaci kudarcok megoldása, a túlzott monopóliumok kialakulásának megakadályozása, a „közös” társadalmi célok sikeresebb elérése és leginkább a gazdasági növekedéshez, a fejlődéshez való hozzájárulás (például olcsó fejlesztési hitelekkel - lásd Andrianova és szerzőtársai [2010]). ${ }^{2}$

A privatizáció mellett szóló hagyományos érvek ezzel szemben a verseny fokozása, a hatékonyság javítása, az állami járadékvadászat leküzdése, a versenyképesség növelése, a tevékenységi és földrajzi korlátok gyorsabb lebontása és legfőképp itt is a gazdasági növekedéshez való hozzájárulás. Az elemzések az állami tulajdonú bankok közül leginkább a nem kereskedelmi bankok, a fejlesztési és export-import bankok pozitív szerepét tudják kimutatni. A másik oldalon ezekkel a bankokkal szemben is gyakran megfogalmazódik a rossz kontroll miatti túlzott kockázatvállalás, illetve a politikai korrupció veszélyének az aggálya.

Az empirikus tanulmányok nem igazán támasztják alá az állami bankok müködése mellett szóló érveket. Bár kimutatható, hogy bizonyos állami bankok hozzájárulnak a gazdaság fejlődéséhez, sőt stabilitási szempontból is mutathatnak előnyöket, de az esetükben rendszeresen megjelenő korrupció, az állam folyamatos beavatkozása és a gyenge állami bankok folya matos megmentése - azaz a „politika” megjelenése - miatt a nemzetközi vizsgálatok az állami bankok gyengébb teljesítményét mutatják ki (Hainz-Hakenes [2008]). Ezek a széles empirikus alapra támaszkodó elemzések azt jelzik, hogy az állami bankok nem hatékonyan osztják el a rendelkezésre álló erőforrásokat, az így létrejövő rendszer drága szolgáltatásokhoz és a magánbankrendszerekénél drágább pénzügyi közvetítéshez vezet, melegágyául szolgál a korrupciónak és a kockázatos pénzosztásnak.

Mindez éppen visszafogja az elösegíteni kívánt gazdasági növekedést, miközben ugyanúgy bekövetkeznek piaci kudarcok (bankösszeomlások, bankpánikok), azaz az állami bankok sokkokkal szembeni ellenálló képessége gyengébb (La Porta és

\footnotetext{
${ }^{2}$ Az állami versus magántulajdonú bankokat elemző empirikus írások a vizsgálati körükbe a speciális célú, az általános kereskedelmi banki szabályozás alól kivont pénzügyi intézményeket nagyon sokszor bevonják, így a fejlesztési bankokat és az exportfinanszírozó bankokat. Pedig ezek a pénzügyi intézmények nem hasonlíthatók össze a többségi államú tulajdonú kereskedelmi bankokkal, így a vizsgálatunkból kihagytuk őket.
} 
szerzőtársai [2002]). ${ }^{3}$ A szakirodalom megállapítása szerint azokban a kevésbé fejlett országokban nagyobb az állami tulajdon részesedése, ahol kevésbé biztosított a tulajdonjogok védelme, nem hatékony az állam, elmaradott a pénzügyi rendszer. Ezekben általában alacsonyabb a növekedési ütem, és kevésbé mély a pénzügyi közvetítés ( $L a$ Porta és szerzötársai [2002], Megginson [2005]).

Ezt azállítást későbbi tanulmányok árnyalják, arra mutatva példát, hogy amennyiben a pénzügyi és politikai rendszer fejlett és stabil, akkor az állami bankok növekedést visszafogó szerepe is mérséklödhet: Körner-Schnabel [2010] is leszögezi azonban, hogy azokban az országokban „ahol a politikai döntéshozók relatíve szabadon követhetik saját céljaikat, erös negatív hatás mutatható ki az állami tulajdon növekedésre gyakorolt hatásában" (5. o.). Vagy ahogy a Világbank tanulmánya fogalmaz „Az állami bankok hitelezése viszszaesés idején képes pozitív, stabilizáló szerepet betölteni, de nagyon gyakran a források téves allokációjához és a közvetítés minőségének romlásához vezet" (World Bank [2012]).

A 20. században hosszú ideig Európa legtöbb országában az állami tulajdon általános volt, tömeges privatizációra - nemcsak a volt szocialista országokban, hanem például Olaszországban, Franciaországban, Belgiumban, Svájcban is - a nyolcvanas-kilencvenes években került sor (Megginson [2005]). Mindezek eredményeként az Európai Unió bankszektorában a válságot megelőzően 10 százaléknál magasabb állami tulajdon már csak Lengyelországban, Szlovéniában (közösségi tulajdon) és a „Landesbankok” révén Németországban volt (MNB [2014]).

Bár a politikailag és pénzügyileg fejlett országokban valóban találunk sikeres, jól müködő, válságellenálló állami bankokat (például a svájci Zürcher Kantonbank), de Európa legtöbb országában az állami bankok többsége nem bizonyult ellenállónak a válság idején. Így például a német tartományi bankok a közelmúlt pénzügyi válsága során kivétel nélkül megrendültek, valamennyien állami tőkeemelésben részesültek, többet össze kellett vonni, így mindössze öt erősen megtépázott tartományi bank maradt életben. ${ }^{4}$ A szlovén bankrendszer is összeomlott a válság alatt, ${ }^{5}$ a szlovén költségvetést megrendítő állami tőkeemeléssel lehetett csak a szektort életben tartani (Balogh [2015]). A válság idején megváltozott az állam szerepe: több tucat magánbank került olyan helyzetbe, hogy életben maradásuk csak állami segítséggel volt lehetséges. Így számos országban került sor a megrendült magánbankok esetében állami tőkeemelésre, bankmentő csomagok kidolgozására. ${ }^{6}$

\footnotetext{
${ }^{3}$ La Porta és szerzötársai [2002] mára széles körben elfogadott vizsgálatait természetesen számosan vitatják, a válságot követően több fórumon is velük ellentétes eredményeket mutatott be Adrianova és szerzőtársai [2010], de az ezeket az eredményeket megalapozó modell egyelöre több ponton megkérdőjelezhető, és nem vált általánosan elfogadottá.

${ }^{4}$ http://www.ft.com/intl/cms/s/0/92a9493a-0dd4-11e4-b149-00144feabdc0.html\#axzz4BYz3PRkd.

${ }^{5}$ „Ténylegesen nem a közvetlen állami tulajdonú, hanem a hazai magánbefektetők és állami vállalatok és intézmények tulajdonában álló bankok felelősek az óriási veszteségszámláért, amelyek gyenge kockázatkezeléssel, a vállalatok és bankok közti szövevényes összefonódásokkal, nem transzparens társaságirányítással, továbbá a helyi és országos politikusok gyakori beavatkozásával jellemezhetők.” (Balogh [2015] 102. o.)

${ }^{6}$ „Az EU versenyhatósága 2008 és 2014 októbere között több mint 450 döntést hozott a tagországok pénzügyi szektorának nyújtható támogatásokról. A bankmentéseket itt bonyolította ugyanis, hogy az általánosságban tiltott állami támogatás - az eredetileg is sok kivétellel tarkított - európai uniós szabályozása brüsszeli jóváhagyáshoz kötötte a nemzeti kormányok döntéseit.” (Voszka [2015a] 726. o.)
} 
Az állami tulajdonszerzés deklaráltan válságkezelési céllal, átmeneti időszakra és magas büntetőkamat mellett valósult meg. 2015-re az amerikai bankrendszer teljes egészében reprivatizálódott (Voszka [2015a]), és az európai bankrendszerben is jelentősen mérséklődött az állami tulajdon, noha az európai bankunió létrejöttét követően az EKB felügyelete alá került 100 jelentős bankcsoportból 11 még mindig „államosított" címkét visel (Schoenmaker-Vernon [2016]). Miként a korábbi válságok esetében a kereskedelmi bankokban megjelenő állami tulajdon jelenleg is inkább átmeneti jelenségnek tekinthetö, üzleti célú állami tulajdonszerzésre nincs példa (Liikanen [2012]). A válságkezelés, a reorganizációs célú részleges vagy teljes államosítás indoka a betétesek védelme, és nem az üzleti célú befektetés. A befektetett állami pénzek felhasználásával minden esetben az államnak el kell számolnia.

A magyar kétszintű bankrendszer története számos olyan egyedi esettanulmányt tud felmutatni, amely a többségi állami banktulajdon kudarcait tárja fel (például Király [2005], Várhegyi [2002]), és - legalábbis eddig - egyetlen olyat sem, amely ennek ellenkezöjét igazolná. A magyar kétszintű bankrendszer kialakítására a rendszerváltást megelőzően került sor (1987), így az új kereskedelmi nagybankok állami tulajdonban voltak. Az állam nemcsak közvetlen, hanem közvetett banktulajdonos is volt, mivel a bankok legnagyobb ügyfeleit jelentő állami nagyvállalatok is tulajdonossá váltak az új bankokban.

Azállami tulajdonú nagybankok a rendszerváltást követő években jelentős mértékü rossz hitelt halmoztak fel, 1993-ra többségükben elvesztették tökéjüket, így végül valamennyit konszolidálni kellett (Várhegyi [2002]). A konszolidációt követően a nagybankokat kivétel nélkül privatizálták, az OTP-t a tözsdén keresztül, a többit külföldi szakmai tulajdonosoknak adták el (Függelék F1. táblázat). Az állami tulajdon - ahogy az az 1. ábrán is látszik - az évtized végén szinte eltűnt a magyar bankszektorból.

\section{1. ábra}

Az állami és a magántulajdonú bankok piaci súlya, 1988-2015

\section{Százalék}

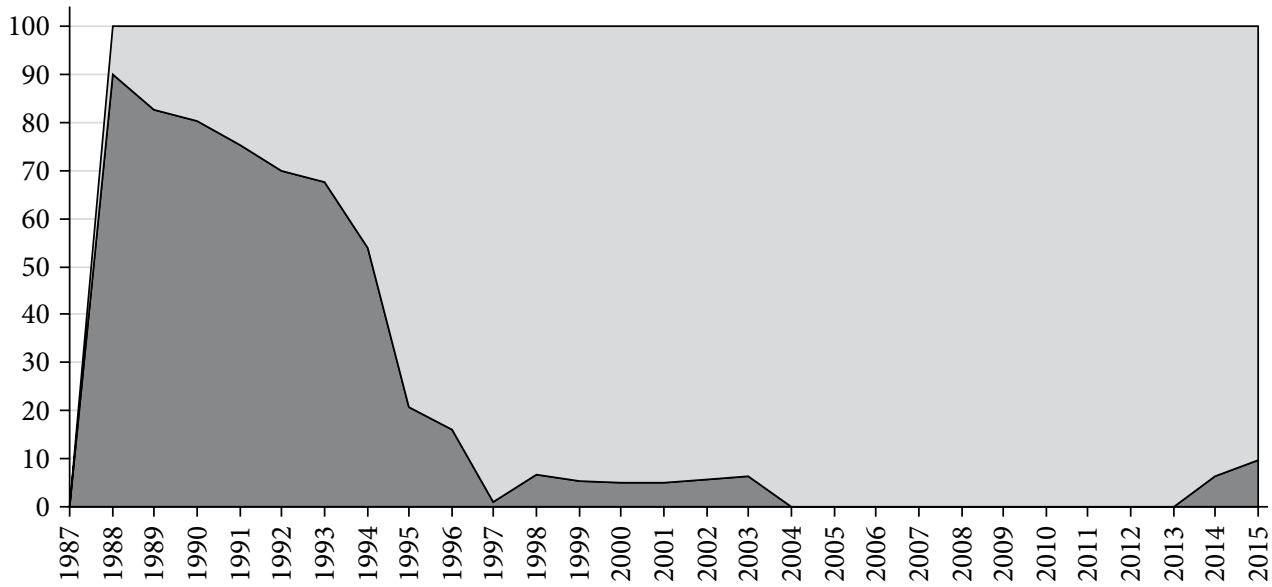

Többségi állami tulajdon Többségi magántulajdon

Forrás: 1988-2002: Pénzügyi Almanach, 2003-2015: Aranykönyv, saját számítások. 
Az állam két szerepben jelent meg újra tulajdonosként a piacon: egyrészt mint piacépítő (az FHB 1997-es alapítása), másrészt mint válságkezelö (a Postabank 1998-2003-as konszolidációja), majd 2003-at - a két bank sikeres privatizációját követően az állam ismét kivonult a piacról.

A nemzetközi tendenciáktól eltérően a magyar állam 2010 utáni újbóli megjelenése a bankpiacon meghatározóan nem válságkezelési céllal történt, sokkal inkább üzleti célúnak minősített bank-, illetve bankrészesedés-vásárlásokat figyelhettünk meg.

- 2013. JÚ NIUS: GRÁNIT BANK • A magyar állam tőkeemeléssel 49 százalékos részesedést szerzett a Gránit Bankban. A tulajdonszerzés a korabeli sajtónyilatkozatok szerint kifejezetten üzleti célú volt, egyelöre nem megítélhető, mennyire volt sikeres. ${ }^{7}$

- 2013. JúNiUs: SzÉchENy I BANK ${ }^{8} \bullet A z$ előző tranzakcióval egy időben a magyar állam 49 százalékos részesedést szerzett a Széchenyi Bankban, mivel „jó üzleti lehetőséget látott” a bankban, amely akkor tízéves tervében a vidéki Magyarország fejlesztését tüzte zászlajára a vidéki hitelszövetkezetek „háttérbankjaként”. A bankot 214 áprilisában tőkerendezésre szólította fel az MNB, 2014 decemberében pedig megvonta müködési engedélyét. ${ }^{9} \mathrm{Ez}$ az üzleti célú befektetést így egyértelmüen kudarcnak ítélhető.

- 2013. Augusztus: TAKARÉKBANK • Az állam már korábban (2013 márciusában az MFB révén) a DZ Bank kivásárlásával 35,5 százalékos részesedést szerzett a Takarékbankban. A 2013. augusztusi rendkívüli közgyülésen a júniusban megjelent integrációs törvény alapján ${ }^{10}$ a Magyar Posta 654,7 milliós (19,3 százalékos) tőkeemelésével a magyar állam többségi tulajdonos lett. ${ }^{11} \mathrm{~A}$ Takarékbank államosítása azonban valójában úgynevezett tranzitállamosítás volt. ${ }^{12} \mathrm{Az}$ állami tulajdon fokozatosan eltűnt, és az állam helyén az FHB Bank jelent meg mint meghatározó magántulajdonos. Az FHB-nak ugyanis 25 százalékos részesedése van abban a Magyar Takarék Befektetési és Vagyongazdálkodási Részvénytársaságban, amelyik 2014 augusztusában (hosszú jogi huzavonát követően) „nyílt tenderen” a magyar államtól megszerezte

${ }^{7}$ „A Nemzetgazdasági Minisztérium lapunk kérdéseire adott válaszai szerint ezek üzleti célú befektetések, amelyeknek hozama »hosszabb távon meghaladja az iparági átlagot «. A tárca szerint az unióban tiltott állami támogatás kritériumai közül egyik sem merülhet fel, miután »teljes mértékben piaci logikájú befektetés történik«, az üzleti terv alapján ugyanis rövid időn belül megtérülő tőkeemelésekről van szó.” http://nol.hu/gazdasag/demjan_es_torocskei_bankjaba_is_beszall_az_allam-1396149.

${ }^{8}$ A Széchenyi Bank jogelődjét, az SPE Bankot kétmilliárd forintos jegyzett tőkével a Kajmán-szigeteken bejegyzett SPCP Hungarian Holdings Ltd. alapította 2008-ban. 2010-ben eredeti tulajdonosa a részvények 100 százalékát eladta a T\&T Ingatlanforgalmazó és Vagyonkezelő Zrt.-nek. A Bank neve előbb Helikon Bankra, majd alig egy hónapon belül Széchenyi Bankra változott.

${ }^{9}$ A támogatni kívánt hitelszövetkezetek közül a zalai Széchenyi Hitelszövetkezet 2015 márciusa óta felszámolás alatt van, a Magyar Vidék hitelszövetkezet végelszámolását 2015 januárjában rendelte el az MNB, a Szentesi és a Tiszántúli Hitelszövetkezet még működik.

${ }^{10}$ 2013. évi CXXXV. törvény a szövetkezeti hitelintézetek integrációjáról és egyes gazdasági tárgyú jogszabályok módosításáról, továbbiakban: integrációs törvény.

${ }^{11} \mathrm{http}: / /$ www.takarekbank.hu/takarekbank/hu/kozpontibank/magunkrol/evesesgyorsjelentesek kozzetetelek/archiv/kozzetetelekjogsz2013/newsCollection/01114/text_files/file0/Kozgyulesi\%20 hatarozatok\%2020130827.pdf.

${ }^{12}$ „.... amelynek végső célja, hogy a korábban autonóm takarékszövetkezeti szektort a kormány által kijelölt üzleti körök kezére játsszák" (Várhegyi [2013] 253. o.). 
a Takarékbank részvénypakettjének 54,83 százalékát. ${ }^{13} \mathrm{~A}$ tranzitállamosítás hátterére és további fejleményeire visszatérünk.

- 2014. JÚLIUS: MKB BANK • A magyar állam 55 millió euró vételárért 99,99 százalékos részesedést vásárolt az $\mathrm{MKB}$ Bankban. ${ }^{14} \mathrm{~A}$ tranzakció során az eladó Bayerische Landesbank elengedte leánybankja 270 millió euró anyabanki tartozását. A befektetés kifejezetten hangsúlyozott „üzleti célját” kétségessé tette, hogy a szanálási törvény alapján ${ }^{15}$ a Magyar Nemzeti Bank 2014 decemberében szanálás alá vette az MKB Zrt.-t. A bank szanálása, a portfóliótisztítás 2015 decemberében zárult le. A szanálást követő tenderen 37 milliárd forint vételárért az MKB-ban magán-tőketársaságok szereztek többségi tulajdont. ${ }^{16}$ Mivel a privatizáció a tanulmány leadásának időpontjában nem fejeződött be, még nem történt meg a pénzügyi teljesítés, így a végső tulajdonosok személye egyelöre nem ismert. A Bank esetében keveredik az állam üzleti célú befektető és a kríziskezelő szerepe, így az ügylet egésze a reprivatizációt követően is nehezen ítélhető meg.

- 2015. FEBRUÁR: BUDAPEST BANK • A válságot követően a bankot tulajdonoló General Electric központilag döntött a cégcsoport pénzügyi ágazatának leépítéséröl. A magyar állam deklaráltan üzleti célú befektetésként a Corvinus Nemzetközi Befektetési Zrt.-n keresztül 700 millió dolláros vételárért vásárolta meg a Budapest Bank 100 százalékos tulajdonrészét. ${ }^{17}$ Ennek a befektetésnek az üzleti eredményét egyelöre nem lehet megítélni, mivel a tanulmány leadásának időpontjában még nem indult meg a bank magánosítása.

- 2015. FEBRUÁR: ERSTE BANK • 2015. február 9-én jelentette be az Erste Group, hogy a Magyar Kormánnyal és az EBRD-vel kötött megállapodás keretében mind az EBRD, mind a Magyar Kormány 15-15 százalékos tulajdonrészt szerez tőkeemelés formájában az Erste Magyarország Nyrt.-ben. ${ }^{18}$ A magyar állam tulajdonszerzése

${ }^{13}$ A Takarékbank állami tulajdonrészének értékesítését oly módon írták ki, hogy a tenderen a többségi takarékszövetkezeteket tömörítő Országos Takarékszövetkezeti Szövetség nem tudott indulni (https://www.mfb.hu/aktualis/sajtokozlemenyek/lezarult-takarekbank-adasvetele).

${ }^{14}$ A Magyar Nemzeti Bank H-EN-I-779/2014. számú határozata.

${ }^{15}$ 2014. évi XXXVII. törvény a pénzügyi közvetítőrendszer egyes szereplőinek biztonságát erősítő intézményrendszer továbbfejlesztéséről. Jelenleg is szakmai vita folyik arról, hogy a 2014 nyarán az állam által megvásárolt MKB-t mennyiben volt indokolt 2014 decemberében szanálási eljárásba vonni. Kellő publikus adat hiányában külső szemlélőként ez a vita nem dönthető el.

${ }^{16}$ „A Magyar Nemzeti Bank, mint szanálási hatóság 2016. március 31-én döntött az MKB Bank Zrt. piaci értékesítési eljárásában a nyertes pályázó kiválasztásáról. A piaci értékesítés kötelező ajánlattételi szakaszában beérkezett - MKB 100 százalékos részesedésére vonatkozó - három ajánlat közül a legmagasabb vételárat, 37 milliárd forintot kínáló, a Blue Robin Investments S.C.A., a METIS Magántőkealap és a Pannónia Nyugdíjpénztár, a CIG partnerség tagja által alkotott konzorcium résztvevői lesznek a döntés értelében az MKB Bank Zrt. új tulajdonosai, 45-45-10\% arányban. Az Európai Bizottság által szorosan felügyelt értékesítési eljárás a zárási feltételek teljesülését (ideértve a nyertes konzorcium tagjai befolyásszerzésének engedélyezését) és a vételár megfizetését követően a tervek szerint 2016. június 30-ig lezárul." https://www.mnb.hu/sajtoszoba/sajtokozlemenyek/2016evi-sajtokozlemenyek/az-europai-bizottsag-szoros-felugyelete-mellett-kivalasztasra-kerultek-azmkb-bank-zrt-uj-tulajdonosai.

${ }^{17}$ A Magyar Nemzeti Bank H-EN-I-345/2015. számú határozata, 2015. június 18. http://alk.mnb.hu/ data/cms2432016/keksz_11259364.pdf.

${ }^{18}$ https://www.erstebank.hu/static/internet/download/150209_Press_release_GoH_Erste_EBRD.pdf. 
a tanulmány leadásának időpontjában még nem történt meg, így egyelöre ennek a befektetésnek az üzleti értéke sem határozható meg.

Valamennyi üzleti célú bankvásárlás deklaráltan átmeneti befektetés: az állam mint egy pénzügyi befektető (mint egy magántőkés társaság) - azaz nem válságkezelöként - a gyors hozam reményében, gyors privatizációt ígérve vásárolt be a vásárlás pillanatában állami tőkeemelésre nem szoruló bankokban. Ezt a típusú állami szerepvállalást az irodalom nem tárgyalja, nincs rá nemzetközi példa. A bemutatott esetek egy részében az üzleti cél erősen megkérdőjelezhető (Széchenyi Bank csődje, MKB szanálás alá vétele), más esetben a szinte azonnali reprivatizáció miatt mindenféle beavatkozási cél megkérdőjelezhetö (Takarékbank), a többi esetben egyelöre nincs lezárt ügylet. Mindezek alapján legalábbis egyelőre nem igazolható, hogy az állam tulajdonszerzése a bankrendszer ellenálló képességének növelését szolgálta.

\section{Belföldi versus külföldi tulajdonú bankok}

A tulajdonosi struktúrával kapcsolatban az állami versus magántulajdon kérdés mellett a legintenzívebb a belföldi versus külföldi tulajdont érintő vita. A kilencvenes évek elemzései a külföldi tulajdonos hatékonyságnövelö, pénzügyi közvetítést könynyítő szerepét emelték ki - ezt figyelhettük meg Magyarországon is. A válság újraértelmezte a külföldi tulajdonú bankok szerepét. Míg az egyáltalán nem egyértelmű, hogy a hazai bankokénál jelentősebb szerepük lett volna a válság előidézésében, addig az tényszerűen igazolható, hogy a válság alatt az anyabankok egyértelmüen likviditás- és tőkepótló szerepet töltöttek be, a külföldi tulajdonú bankok ellenállónak bizonyultak a válsággal szemben. A válságot követően nem rajzolódik ki éles különbség a hazai és külföldi bankok növekedést támogató hitelező szerepében. A következőkben ezeket a megállapításokat részletezzük.

A válságot megelözően széles körben elfogadott nézet volt, hogy a fejlődő országokban a külföldi banktulajdon megjelenése hozzájárult a piaci merevségek oldódásához, az ügyfelek jobb kiszolgálásához, a modern banktechnika elterjedéséhez, a bankrendszer hatékonyságának növekedéséhez, a verseny erősödéséhez, a pénzügyi közvetítés költségeinek csökkenéséhez, a hatékonyság növekedéséhez és mindenekelött nagyobb intézményi és így gazdasági stabilitáshoz vezetett (Claessens-Jansen [2000], Majnoni és szerzötársai [2003]). Az átalakuló országokban a külföldi bankok jobb teljesítményét a hatékonyabb müködés indokolta (Havrylchyk-Jurzyk [2011]). A külföldi tulajdonú bankok megjelenése a verseny erősödésén keresztül a többi bankot is hatékonyabb müködésre sarkallta, ezzel növelve a bankrendszer jövedelmezőségét és stabilitását, ami végső soron az egész gazdaságra pozitív hatást gyakorolt.

Magyarországon a többségi belföldi tulajdonú bankrendszer a transzformációs válság idején összeomlott, a bank- és adóskonszolidációra során az akkori GDP több mint 10 százalékát kellett fordítani (Langmár-Papp [1996], Ábel-Szakadát [1997], Várhegyi [2002], Király [2005]). Hasonló bankkonszolidáció játszódott le ezekben az években a 
régió legtöbb országában is. ${ }^{19}$ Az állami és nagyon sok esetben az új, nem kellő tőkeerejü magánbankok egymás után mentek csődbe, ugyanakkor hiányzott a friss tőke és forrás a bankrendszer további működéséhez. Az 1993-1994-es bankkonszolidációt követő évek privatizációs hulláma során a legtöbb hazai nagybank külföldi szakmai tulajdonos kezébe került, kivéve az OTP-t, amely tőzsdei kibocsátás révén került többségi külföldi tulajdonba. Ennek ellenére mind a statisztika, mind az elemzők továbbra is „magyar” banknak tekintik az OTP-t, mivel székhelye és így döntési centruma is Magyarországon van, és a döntéseket meghatározó igazgatóság és menedzsment magyar. ${ }^{20}$

A 2. ábrán a belföldi és a külföldi tulajdonú bankok piaci részesedésének alakulását mutatjuk be. Külön egységként kezeljük az OTP Csoportot - így a tendenciák elemzése is könnyebb.

2. ábra

A belföldi bankok, az OTP, a külföldi nagy- és kisbankok, valamint bankfiókok piaci súlya, 1988-2015

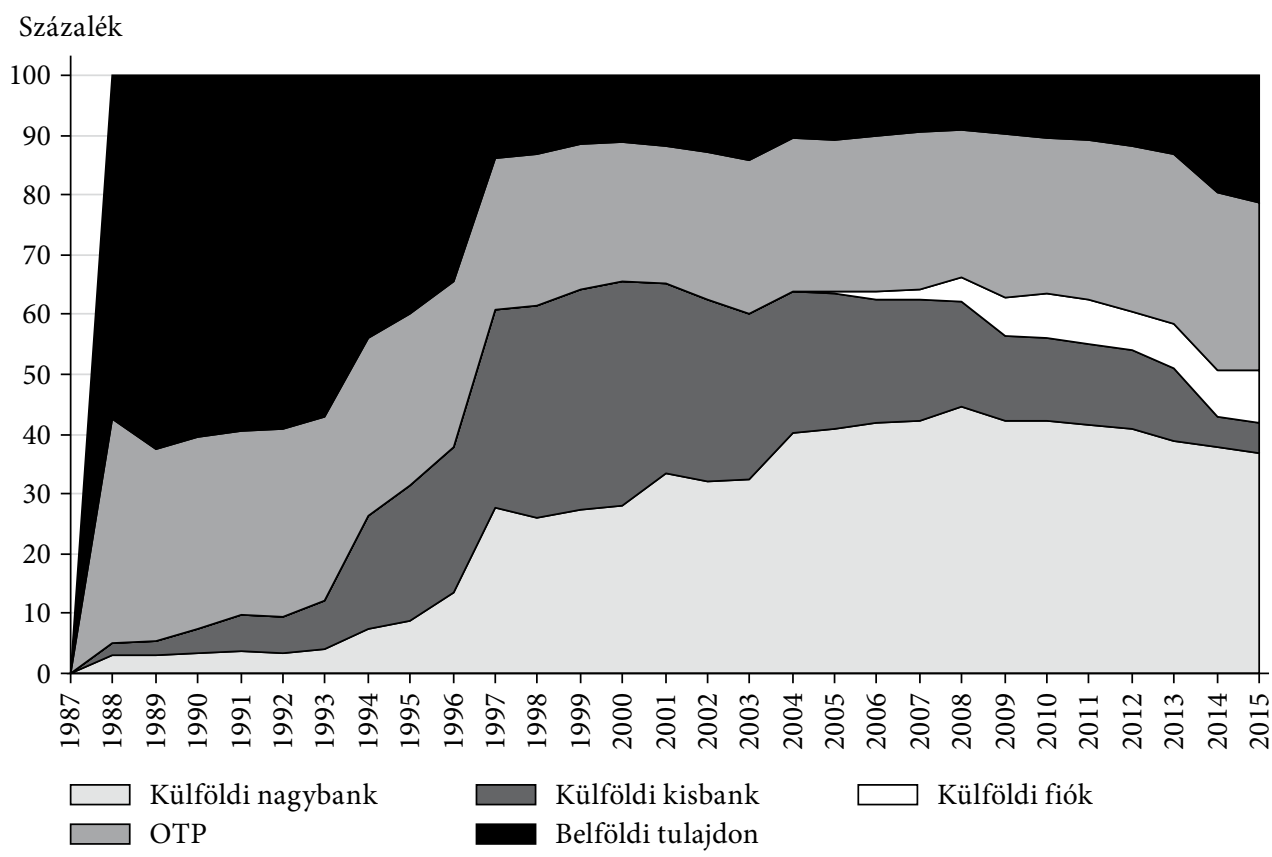

Megjegyzés: az egyes intézmények minden évben az év végi jellegüknek megfelelően vannak besorolva.

Forrás: 1988-2002: Pénzügyi Almanach, 2003-2015: Aranykönyv, saját számítások.

\footnotetext{
${ }^{19}$ Régión a válság előtt az Európai Unióba belépett, a volt „keleti blokkhoz” tartozó országokat értjük: Bulgária, Csehország, Észtország, Lengyelország, Lettország, Litvánia, Magyarország, Románia, Szlovákia, Szlovénia, mert az empirikus tanulmányokban is ezeket az országokat szokták együtt vizsgálni.

${ }^{20}$ Az OTP magyar vagy külföldi bankként való besorolásáról nincs teljes egyetértés a szakmán belül sem: a többségi külföldi tulajdon miatt valószínüleg több empirikus elemzésben mint külföldi bank jelenik meg. Mi az elemzésünk során a hazai statisztikai gyakorlatot követve az OTP-t „magyar bankként" kezeljük.
} 
A kilencvenes évek transzformációs válságát követő átalakulás tisztán kivehető: a hazai tulajdonú bankok piaci részesedése visszaesett: az OTP Csoport és a közösségi tulajdonú takarékszövetkezetek kivételével a hazai tulajdonú bankok gyakorlatilag eltüntek a piacról. Helyüket külföldi tulajdonú leánybankok vették át.

Némi késéssel a magyarországihoz hasonló folyamatok játszódtak le a többi régióbeli ország bankrendszerében is. A kétezres évek közepére Szlovéniát kivéve valamennyi ország bankszektorának 70-99 százaléka külföldi bankok kezébe került (Ábel-Szakadát [1997], Várhegyi [1998], [2002], Banai-Király-Várhegyi [2010]). A régióban megjelent nemzetközi bankcsoportok ${ }^{21}$ saját jól felfogott érdeküket követték: a saját országukban telítödött a banki piac, alacsony volt a növekedés, alacsonyak voltak a marzsok és a profitok, a régió viszont dinamikus jövő előtt állt: felzárkózás az EU-hoz, jövedelemnövekedés, bővülő banki szolgáltatások, kecsegtetően magas marzsok és profitok, amelyek aztán a piacra belépő külföldi bankok versenyének következtében radikálisan csökkenni kezdtek. A stratégiai befektetőként megjelenő bankok olyan piacot kerestek, ahol versenyelőnyük volt, és kihasználva tapasztalatukat, az otthoninál magasabb jövedelmezöséget tudnak elérni viszonylag csekély többletkockázattal. ${ }^{22}$

A várakozások helyesnek bizonyultak. A válság előtti mintegy másfél évtizedben a régió az egyik leggyorsabban növekvő térség volt a világon, a várt felzárkózási folyamat, egy-egy megtorpanással ugyan, de beindult. Ennek részeként a korábbi gazdasági struktúra fokozatosan átalakult és a Nyugat-Európában megszokott felé közelített. A bankok komoly pozíciókat építettek ki a térségben, és a bőséges, olcsó likviditás segítségével támogatták a térségre jellemző hitelexpanziót. Az empirikus tanulmányok a verseny növekedését, a közvetítői költségek csökkenését, a hatékonyság emelkedését, a pénzügyi stabilitás erösödését mutatták ki (Majnoni és szerzötársai [2003], Várhegyi [2004], Banai-Király-Várhegyi [2010]). Bonin és szerzötársai [2004] azért is jelentős tanulmány, mert cáfolja, hogy a belföldi csoport teljesítményét az állami bankok teljesítménye húzta volna le, azaz a külföldi tulajdon a belföldi magántulajdonnál is jobban teljesített.

A pénzügyi válság azonban újragondoltatta a külföldi banktulajdon megítélését: számos elemzés foglalkozott szerepükkel a válság előidézésében, a válság alatti likviditási és tőkeválságban és a válságot követő hitelezési pangásban, illetve fellendülésben. Végleges következtetések természetesen még nincsenek, hiszen a válság számos utóhatása még csak most válik mérhetővé, a vizsgálatokhoz szükséges adatbázisok összeállítása is komoly erőfeszítéseket követel. A különböző megközelítésekről jó összefoglalót ad Claessens-Van Horen [2014], Schoenmaker-Wagner [2011], illetve MNB [2014] 6. fejezet.

\footnotetext{
${ }^{21}$ Legjelentősebb pozíciókat a földrajzi közelséget is élvező osztrák és olasz bankcsoportok alakították ki, illetve a Baltikumban a svéd és norvég, a Balkánon a görög bankok játszottak még jelentős szerepet.

${ }^{22}$ „1989-ben ... Ausztria a hidegháború határterületéből az integráció központi országa lett. A földrajzi közelség, a kulturális hasonlóságok és a közös történelem Ausztria számára komoly versenyelőnyt jelentett ezen új piacokon, amit képes volt kihasználni. 1989 után így a stratégia egyértelművé vált: Irány Keletre!”- foglalta össze az osztrák jegybank elnöke az osztrák bankok meghatározó motívumait (Nowotny [2009]).
} 
A válságot megelőző periódust vizsgálva az eddig megjelent széles adatbázison végzett empirikus elemzések inkább cáfolták azt a korábbi, egyszerü, föleg állományi statisztikákra alapozott nézetet, hogy a devizahitelezési boomért, a hitelezési standardok lazításáért, a hitelezési buborék kialakulásáért elsősorban a külföldi bankok lettek volna felelősek. Az újabb, a régió több országára kiterjedő ökonometriai elemzések inkább azt mutatták, hogy a hazai és külföldi bankok viselkedésében nem volt szignifikáns eltérés a válságot megelőzően, egyaránt részt vettek a kockázatalapú versenyben (Brown-De Haas [2010], Beckmann és szerzőtársai [2015]). A hitelbuborék ugyanazon külföldi bankcsoportok jelenléte mellett is eltérően alakult az egyes országokban: a balti országokat, Bulgáriát és Magyarországot jellemezte a háztartási szektorban megjelent hitelbuborék, amely a válságban kipukkadt (Lahnsteiner [2013]), Csehországban, Romániában, Szlovákiában vagy Lengyelországban ilyen buborék nem alakult ki, sőt Csehországban és Szlovákiában a hitelbuborék kialakulását elösegítő devizaalapú hitelezés is ismeretlen volt. Empirikusan nem igazolódott, hogy a külföldi bankoknak a válság elöidézésében játszott szerepe szignifikánsan megkülönböztethetö a nem külföldi tulajdonú bankok hasonló, túlzott hitelfelvételre ösztönző szerepétöl.

A válság elötti éveket Magyarországon is a többségi külföldi tulajdonú bankok dominanciája és gyors növekedése jellemezte. A külföldi tulajdonú bankok az ezredfordulóig inkább a vállalati piacon versenyeztek egymással és a helyi bankokkal. Az ezredforduló előtti években indult meg a lakossági piaci verseny. 2004-től a devizahitelezés lakáshitelpiacra való kiterjedésekor a külföldi bankok elsősorban az olcsó anyabanki források és a lejjebb szorított marzsok segítségével megtörték az OTP-hegemóniáját a lakossági piacon (Banai-Király-Nagy [2010]). A külső forrásra való támaszkodás ekkoriban nem csak a leánybankokra volt igaz, esetenként az anyabankok maguk is 100 százalékot meghaladó hitel/betét arányt produkáltak. Ez azt jelenti, hogy végső soron a hazai leánybankok a külső tőkepiacokra voltak utalva, vagy közvetlenül, vagy az anyabankon keresztül. A versenyben azonban azok a belföldi tulajdonú bankok is részt vettek (például OTP vagy FHB), amelyeknek ekkoriban ugyanúgy lehetőségük volt a piacon olcsó devizaforráshoz jutni, mint a külföldi bankoknak.

A 2006-os költségvetési konszolidációt követö kockázatalapú lakossági devizahitelversenyben mind a hazai, mind a külföldi bankok egyre kockázatosabb termékeket kínáltak (svájcifrank- és jenalapú hitelek, szabad felhasználású jelzáloghitel, kezdetben kedvezményes kamatozású hitelek, unit linked hitelek stb.) egyre lazuló hitelezési feltételek mellett (tisztán fedezetalapú hitelezés, hitelfedezetiráta-növekedés stb.), egyre kockázatosabb ügyfelek számára. 2006-ot követően ebben nem volt különbség a hazai és külföldi bankok között.

A válság idején az anyabankok magatartása többféle lehet: a határon átnyúló bankolás elemzésekor találtak empirikus bizonyítékot a „támogató” és a „magára hagyó" magatartásra is (De Haas-Lelyveld [2010], Goldberg [2007], [2009], Cetorelli-Goldberg [2009]). A viták és empirikus tanulmányok egyaránt hoztak fel pro és kontra érveket, árnyalták a külföldi banktulajdonosok szerepét. A régióbeli és ezen belül a magyar - adatok elemzése azonban inkább a válság alatti stabilizáló, forrást és tőkét biztosító, hitelezést fenntartó szerepüket támasztja alá, különösen 
azon országok és bankok esetében, amelyek részesei voltak a Bécsi Kezdeményezésnek (De Haas és szerzőtársai [2012]). Más elemzések ugyanakkor rámutattak, hogy az eurózóna 2011-es válsága a határon átnyúló banki tevékenység következtében visszafogta a régióbeli országok hitelnövekedését is (Avdjiev és szerzőtársai [2012], Chen-Wu [2014], Ongena és szerzőtársai [2013]).

Az egyedi banki esettanulmányok a külföldi tulajdonú bankok ellenálló képességét mutatták ki. A többségi külföldi tulajdonú bankrendszerek biztonsága sokkal kevésbé rendült meg, mint nyugat-európai társaiké, a válság alatt a külföldi tulajdonosok egyértelmủen helytálltak leánybankjaikért. A multinacionális banki háttér a válság idején segített a válsághatásokat tompítani: „a multinacionális bankholding komoly veszteségek esetén is támogatja leánybankjait tőkével, illetve likviditással. (...) A külföldi bankok jelenléte ugyan nem csodaszer a feltörekvő gazdaságok bankjainak minden gondjára, de a tapasztalatok alapján inkább erősíti a pénzügyi stabilitást, semmint gyengíti azt." (De Haas [2009].)

A válság alatt a külföldi tulajdonos bankok stabilizáló szerepe Magyarországon is dominált: mind tőkével, mind megfelelő források biztosításával bankjaik mögött álltak, a külföldi tulajdon a válság alatt ütésállónak bizonyult (MNB Stabilitási jelentések 2009, 2010 2014). ${ }^{23} 2008$ végéig, azaz a válság első, likviditás szempontjából legsúlyosabb szakaszában kifejezetten nőtt a külföldi (elsősorban anyabanki) források volumene. Ez azt jelentette, hogy az októbert követő, akut likviditási válsággal jellemezhető periódusban az anyabanki finanszírozás mind relatív, mind abszolút mértékben nött. A lejáró külföldi források megújítását többnyire az anyabankok biztosították. A bankrendszereknek általában nem kellett nagyon komoly likviditási feszültségekkel szembenézniük, hiszen a megújítási ráta 100 százalék fölött maradt, vagy még nőtt is. Mint a 2009. áprilisi MNB Stabilitási jelentés írja: „A pénzügyi stabilitás fennmaradásában a külföldi tulajdonosok magyar leánybankjai iránti elkötelezettsége fontos tényező. Az anyabanki háttérrel rendelkezö bankok külföldi forrásainak és devizaswapjainak megújítása eddig zavartalan volt." (MNB [2009] 8. o.) A hazai bankok ezzel szemben a kieső forrásokat csak állami hitellel voltak képesek pótolni (Banai-Király-Nagy [2010]). Mindez cáfolja azt az állítást, hogy a válság idején az anyabankok „kirántották” volna a forrásokat leánybankjaikból. ${ }^{24}$

A bekövetkezett recesszió, a kereslet visszaesése visszavetette a banki hitelezést is, így a külföldi források visszaestek. A bankok - részben anyabanki nyomásra - igyekeztek a válság elötti 100 százalék feletti hitel/betét arányukat radikálisan csökkenteni, a hitelállományt gyorsított ütemben leépíteni, a belföldi forrásbevonást erősíteni. 2009 nyarán azonban a külföldi bankok tulajdonosai aláírták a Bécsi Kezdeményezést, amely szerint a külföldi anyabankok kötelezettséget vállaltak a válságot

\footnotetext{
${ }^{23} \mathrm{https} / / /$ www.mnb.hu/kiadvanyok/jelentesek/penzugyi-stabilitasi-jelentes.

${ }^{24}$ „Emlékszik-e Ön még a pénzügyi válságra? Mi történt az európai pénzügyi válság idején? Ezt beleégették az idegrendszerembe. Az történt, hogy azok a bankok, amelyek pénzügyi válság okán nehéz helyzetbe kerültek, a forrásaikat elkezdték hazavinni. Mert mindenkinek a saját hazája a legfontosabb, ahol az anyaország van.” http://www.kormany.hu/hu/a-miniszterelnok/beszedek-publikaciokinterjuk/meg-kell-vedeni-az-orszag-fuggetlenseget.
} 
megelőző forrásaik szinten tartására (Magyarországon 95 százalék volt az elöírt mérték). Az MNB Stabilitási jelentése 2010 áprilisában azt állapította meg, hogy a külföldi források megújítási kockázatát jelentősen csökkenti az anyabankok elköteleződése. 2010 júliusában a magyar kormány megszakította a tárgyalásokat a Nemzetközi Valutalappal, és ezzel automatikusan felmondta az anyabanki forrásokat szinten tartó Bécsi Kezdeményezést is. Ennek ellenére 2010 végéig az anyabankok nem vonták ki jelentős mértékben forrásaikat, a gyorsított forráskivonás csak 2011től, a kormány úgynevezett kiszorító lépéseinek hatására következett be, de összességében még 2011-ben is magasabb volt a külföldi forrás, mint a válság előtti években ( $M N B$ [2014] 12. o. 8. ábra). Magyarország kivételével a többi régióbeli országban 2010 óta sem következett be jelentősebb forráskivonás.

A tőke szempontjából is stabilitást jelentett a külföldi tulajdon. A meghatározó nagybankokat figyelembe véve, megállapítható, hogy a külföldi anyabankok a válságban jó tulajdonosként, korábbi osztalékkifizetéseiket jócskán meghaladó mértékben emeltek tőkét veszteséges bankjaikban (3. ábra).

\section{3. ábra}

A hét külföldi tulajdonú nagybank ${ }^{*}$ osztalékfizetése és tulajdonosi tőkeemelése, 2001-2014 (milliárd forint)

Milliárd forint

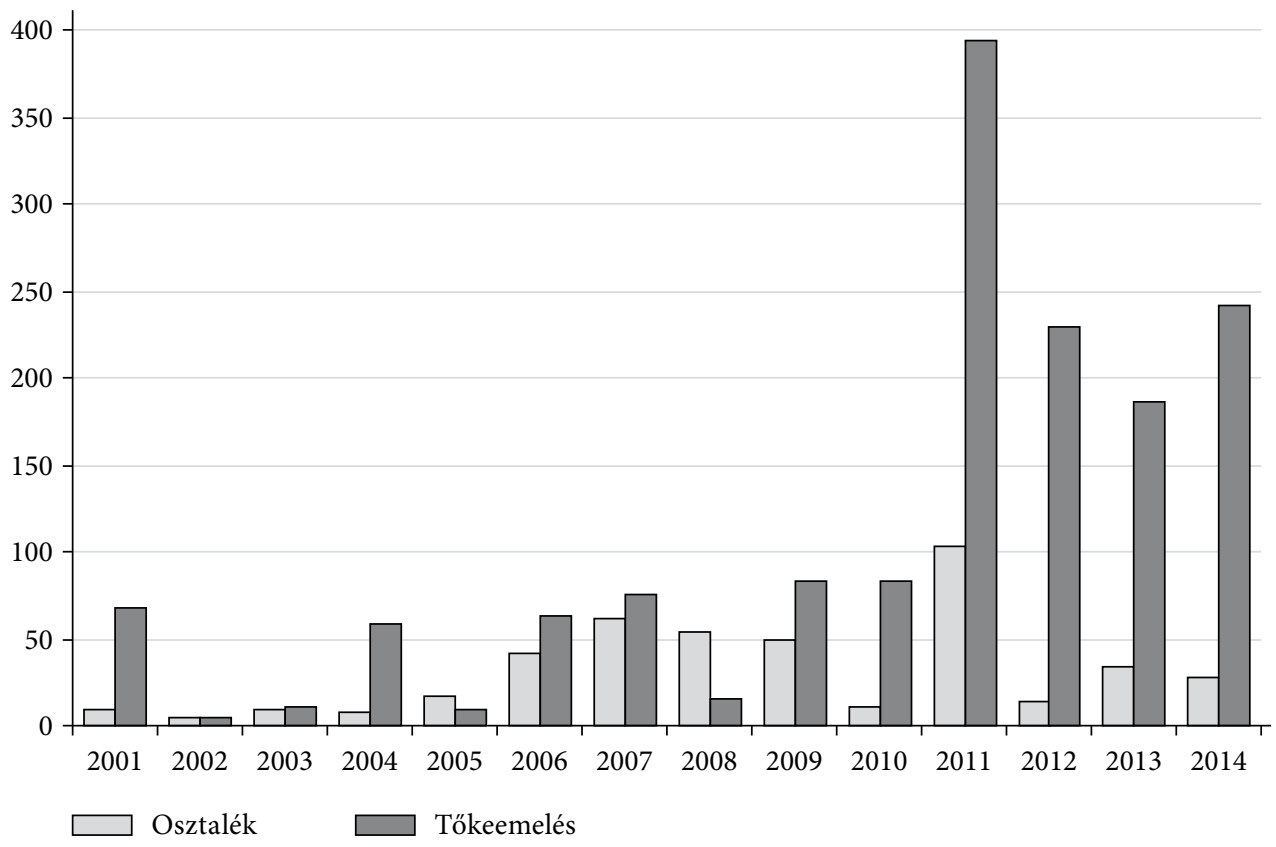

${ }^{*}$ Budapest Bank, CIB Bank, Erste Bank, K\&H Bank, Raiffeisen Bank, UniCredit Bank. Forrás: a hét nagybank éves jelentései.

A 3. ábra egyértelmüen cáfolja, hogy a külföldi anyabankok „kitalicskázták” a fellendülés idején a profitot, majd cserben hagyták bankjaikat: a 2000-es években a 
tőkeemelések mértéke látványosan meghaladja kifizetett osztalékokat. ${ }^{25}$ Sőt valójában a válság elött is az volt megfigyelhetö, hogy a külföldi bankok nyereségük több mint kétharmadát visszaforgatták a régióban, ezen belül a Magyarországon tapasztalt 70 százalék feletti arány a régióban a legmagasabb értékek közé tartozott (MNB [2014] 17. o. 14. ábra). „A válság során az anyabankok veszteséges leánybankjaik tőkemegfelelését tőkeemelés (tőkepótlás) révén biztosították, ami hazánkban mind ez idáig 2009 és 2013 vége között meghaladta az 1000 milliárd forintot." (MNB [2014] 16. o.)

A kiváló MNB-s elemzést egy ponton kell pontosítanunk: a leánybanki veszteségek nem csak a válság hatására keletkeztek: a kormány kiszorító lépései az egyébként tiszta portfólióval rendelkező bankokra is súlyos teherként nehezedtek. Összességében megállapitható, hogy ellentétben az 1990-es évekbeli transzformációs válsággal, amikor a belföldi (elsősorban állami) többségi tulajdonú magyar bankrendszer összeomlott, a 2008-2010 közötti pénzügyi válság idején a többségi külföldi tulajdonú magyar bankrendszer ellenállónak bizonyult, sem forrásait, sem tökéjét, sem hitelezési lehetöségeit nem rombolta le a válság.

A válságot követően Magyarországon megkezdődött a külföldi többségi tulajdonú bankok lassú kiszorítása. 2010-től kezdve a kormányzati kommunikációban egyre hangsúlyosabban jelent meg a többségi belföldi tulajdon megteremtésének szükségessége a bankszektorban. Az eddig bemutatott tényeket figyelmen kívül hagyva, empirikus bizonyítékok nélkül evidenciaként jelent meg, hogy ez a cél biztosítja a rendszer stabilitását: „... a stabilitás érdekében elérendő cél, hogy a külföldi anyabankok váratlan tőkekivonásaitól mentes, stabil, magyar alapokon nyugvó bankrendszer jöjjön létre". ${ }^{26}$

A válság elött jelentős növekedést mutató, a devizahitelezésben aktív külföldi tulajdonú bankok lassú kiszorítása szabályozási lépésekkel kezdődött. „A nemzetközi hitelválság eltérő módon befolyásolta a magyar bankszektor szabályozási környezetét és versenyhelyzetét, mint az érintett országok többségében: kisebb mértékben játszottak benne szerepet a szokásos válságkezelő állami intézkedések, és nagyobb súlyt kaptak a magyar gazdaságpolitika és a politika irányvonalához illeszkedő, "nem szokványos« kormányzati beavatkozások." (Várhegyi [2012] 5. o.) Ezek a lépések: a banki különadó bevezetése 2010-ben, ${ }^{27}$ a végtörlesztés 2011-ben, ${ }^{28}$ a tranzakciós

\footnotetext{
${ }^{25}$ Felmerül, hogy az anyabankok költségként, magasan számított licenc-, lízing- és jogdíjként, tanácsadói díjként, avagy leánybanknak nyújtott hitel magas kamatán keresztül, burkoltan vonták ki az eredményt. Ezt alátámasztó elemzést azonban sehol sem találtunk: ilyen esetekben ugyanis kifejezetten bizonyítani kellene, hogy az anyabank szándékosan túlszámlázott, kimutathatóan a piaci átlag fölötti árat, kamatot, bérleti díjat számolt fel.

${ }^{26}$ http://www.origo.hu/gazdasag/20120717-ezermilliardos-alom-orban-magyar-bankrendszere.html.

${ }^{27}$ A banki különadóról szóló törvényt az országgyülés július 23-án fogadta el. A különadót nem a bank jövedelemtermelő képességével arányosan, hanem a 2009-es mérlegföösszege alapján vetették ki, azaz egyértelmű hátrányba hozta a válság előtti hitelezési fellendülésből részüket kivevő, külföldi tulajdonú nagybankokat, a válság alatt, illetve után alakult kisméretü, többségi magyar tulajdonú bankokkal szemben.

${ }^{28}$ A 2011. évi CXXI. törvény az otthonvédelemmel összefüggő egyes törvények módosításáról (az úgynevezett végtörlesztési törvény) nagy vesztesei a külföldi tulajdonú nagybankok voltak (MNB [2012]).
} 
adó bevezetése 2013-ban, ${ }^{29}$ súlyos versenyhivatali bírság 2013-ban és 2015-ben, ${ }^{30}$ az elszámoltatási törvények 2014-ben, ${ }^{31}$ valamint számos a nemzetközi szabályozástól eltérő helyi bankszabály bevezetése.

A bankokat érintő rendelkezések, szabályok egyes elemei más országok szabályrendszerében is felfedezhetők, azonban valamennyi szabály szinte egyszerre történő bevezetése (rövid, alig hároméves periódusról van szó) a már működő bankok számára olyan többletköltségeket jelent, amelyek ellensúlyozására a szűkülő piacok és a szükülő marzsok miatt nem volt lehetőség. A beavatkozás hozzájárult ahhoz, hogy 2010-2014 között a többségi külföldi tulajdonú bankok fokozatosan veszteségessé váltak, a saját korábbi hibás döntéseikből származó veszteségeket jelentősen megnövelte az állami beavatkozás többletterhe. ${ }^{32}$

Ha egy ország az amúgy is erősen bankkorlátozó szabályozási hullám közepén a saját bankrendszerében még erősebb, nem egy esetben visszamenőleges szabályokat és korlátokat vezet be, azzal nemcsak a saját területén lévő bankokat hozza hátrányos helyzetbe, hanem arra ösztönzi a külföldi tulajdonosokat, hogy a csoport más tagjaihoz csoportosítsák át a bankmüködéshez szükséges forrásokat. Ilyen értelemben a magyarországi bankokat hátrányos helyzetbe hozó adó- és jogszabályok valóban kiváltották a hitelezési fordulatot hátráltató tulajdonosi viselkedést.

A 2. ábrán jól láthattuk, hogy a válság után megkezdődött a külföldi bankok lassú térvesztése: számos bank elhagyta a piacot, több bankot hazai tulajdonosi csoport vett át, és megkezdődött a korábbi leánybankok fokozatos fiókosodása is (lásd Függelék F2. táblázat).

A külföldi tulajdonos határon átnyúló banki tevékenységének intézményi formáját vizsgálva, a fogadó ország szempontjából azt állapíthatjuk meg, hogy ha a fogadó ország pénzügyi rendszere kellően fejlett, akkor előnyösebbnek tünik a leánybanki forma a fiókformával szemben (Fiechter és szerzötársai [2011]). A helyi monetáris és prudenciális szabályozók döntéshozói szempontjából több információt és jobb

${ }^{29}$ A pénzügyi tranzakciós illetékről szóló 2012. évi CXVI. törvény 2013. január 1-jén lépett hatályba. A tranzakciós illeték bevezetését követően jelentősen megnövekedtek a banki tevékenység költségei.

${ }^{30}$ A Gazdasági Versenyhivatal (GVH) 2013. november 19-én kelt döntésével tizenegy pénzintézettel szemben a végtörlesztés korlátozására irányuló, összehangolt magatartás miatt összesen 9,5 milliárd forint bírságot szabott ki. 2015. január 12-én kelt döntésével a BankAdat-adatbázis müködtetéséért 4 milliárdos bírságot szabott ki a Magyar Bankszövetségre. Mindkét büntetés elsősorban a korábbi években meghatározó szerepet játszó, többségi külföldi tulajdonú bankokat sújtotta.

${ }^{31}$ A Kúria jogegységi határozata (6/2013 PJE) alapján az Országgyủlés két törvényt fogadott el: 2014. július 4-én a 2014. évi XXXVIII. törvényt a bankok elszámoltatásáról, 2014. szeptember 24-én pedig a 2014. évi XL. törvényt az elszámolási szabályokról. A törvényekben foglaltak alapján a bankok kötelesek voltak ügyfeleikkel visszamenőleges hatállyal elszámolni az árfolyamrés semmissége és az egyoldalú szerződésmódosítások miatt keletkezett túlfizetéseiket. A két törvény együttesen mintegy ezermilliárd forintos kárt okozott a bankszektornak, mindenekelőtt a válság előtt aktív külföldi tulajdonú nagybankoknak. Valójában semmi sem indokolta, hogy miért vált el egymástól ez a két törvény (Gárdos [2014], [2015]).

${ }^{32}$ Nagyon nehéz pontos becslést adni arra, hogy a bankszektor összes veszteségéből mennyi tulajdonítható a hibás banki stratégiának, mennyi a recessziónak és mennyi a minderre rárakodó állami beavatkozásnak. A Magyar Nemzeti Bank becslése szerint a bankszektor 2009-2013 alatt elszenvedett veszteségéből 13 százalékot okozott a bankadó és 15 százalékot a végtörlesztés. A becslés nem számol a közvetett hatásokkal (MNB [2014] 14. o.). 
ellenőrizhetőséget jelent egy leányvállalat, mint egy fiók, de nagyon éles határok nincsenek a két forma között. A leánybanki megoldás kölcsönösen nagyobb bizalmat, transzparensebb együttmüködési lehetőséget rejt magában. Ha a tulajdonosok egy ország esetében növekvő mértékben a fiókforma mellett döntenek, ez arra utalhat, hogy tartósan, széles körü banki szolgáltatásokat nyújtva nem kívánnak beleágyazódni a politikailag kockázatosnak tartott fogadó ország bankrendszerébe, ahol ez a politikai kockázat a kormányzat folyamatos és jelentős bankpiaci beavatkozását jelenti (Cerutti és szerzőtársai [2007]).

Összességében a szakirodalom és az eddigi banktörténelem azt tükrözi, hogy $a$ régióban a külföldi tulajdonú bankok dominanciája inkább erösitette, semmint gyengítette a pénzügyi stabilitást, a közelmúlt pénzügyi válságában ellenállónak bizonyult, és nem hátráltatta a válságot követő fellendülést. Megítélésünk szerint Magyarországon a külföldi befektetök kiszorítása, a leánybankok helyett a fiókok megjelenése nem erősíti a hazai pénzügyi rendszer stabilitását és ellenálló képességét.

\section{Egy különleges eset: közösségi tulajdonú bankok}

Az állami tulajdon „árnyékában” vizsgálni szokták a más típusú „közösségi tulajdonlásban" müködö intézményeket - a közösségi bankokat (community banks), a takarékszövetkezeteket, a takarékpénztárakat stb. is. Ezek Európában elsősorban Ausztriában, Franciaországban, Finnországban, Hollandiában, Németországban és Spanyolországban terjedtek el, ezekben az országokban a betéti piacon 30-50 százalékos részesedést értek el. ${ }^{33}$

A magyar takarékszövetkezeti szektort nem lehetett a klasszikus értelemben vett „vidék bankjának” tekinteni (Gál-Burger [2013]), ${ }^{34}$ és a pénzügyi piacon betöltött szerepe sem volt igazán jelentős: a takarékszövetkezetek összesített piaci részesedése 2013 elött 5-6 százalék körül ingadozott. A vállalati piacon sosem volt jelentős a szektor szerepe (3-4 százalék körüli), a lakossági hitelpiacon a devizahitelezés felfutásával párhuzamosan, mivel abban nem vett részt, megfeleződött a piaci súlya (10 százalékról 5 százalék alá csökkent), jelentős mértékben csak a lakossági betéti piacon volt jelen, ahol piaci részesedése 16-18 százalék között mozgott (Gál [2012]).

Ezek a hitelintézetek általában helyi közösségek tulajdonában állnak, tevékenységi és földrajzi kiterjedésük korlátozott, tradicionálisan a lakossági és a kisvállalkozói piacon vannak jelen (Liikanen [2012], Périlleux és szerzötársai [2016]). Az elemzések eredménye nem egyértelmü: általában kisebb kockázatvállalás jellemzi őket, mint a nagybankokat, jobban hozzájárulnak egy-egy régió hitellel való ellátásához, eredményük kevésbé ingadozik, ám éppen méretüknél fogva tőkeszegények,

\footnotetext{
${ }^{33}$ A hitelszövetkezetek inkább Írországban, Romániában, Lengyelországban és a Baltikumban terjedtek el.

${ }^{34}$ „... a »klasszikus szövetkezeti« modell alig jelenik meg Magyarországon, azaz a hitelezésben az új piacokon való terjeszkedés nélkül is aktív, helyileg és társadalmilag beágyazott takarékszövetkezet típusa nem jellemző. Következésképpen a hazai szövetkezeti szektor csak az örökségét tekintve a »vidék bankja«." (Gál-Burger [2013] 397. o.)
} 
így mégis nagyobb a sérülékenységük. Az elemzői és a szabályozói konklúzió egy irányba mutat: erős integrációba tömörülve válhatnak stabil, jövedelmező tőkeerős szektorrá (Liikanen [2012], Gál-Burger [2013]). Az európai bankunió 100 kiemelten felügyelt jelentős bankcsoportjából 27 (!) erős takarékszövetkezeti integráció található, mint például a francia Crédit Agricole, BPCE és Crédit Mutuel, a holland Rabo Csoport, az osztrák Raiffeisen Csoport, a német DZ Bank, a spanyol Caixa, vagy az olasz UPIBanka (Schoenmaker-Vernon [2016]). A válságot követő friss elemzések szerint ezek a csoportosulások ellenállóbbnak bizonyultak, kisebb volatilitással élték át a közelmúlt válságos éveit, mint a hasonló nagyméretű magánbankok (GroeneveldVries [2009], Birchall-Ketilson 2009)

A magyarországi takarékszövetkezeti szektort általában a bankszektornál alacsonyabb jövedelmezöség, a rossz hitelek magasabb állománya és alacsony tökeellátottság jellemezte (Gál [2012]). A transzformációs válság során felhalmozódott veszteségek miatt a szektort 1993/1994-ben a többi belföldi bankhoz hasonlóan az államnak konszolidálnia kellett, a Takarékbank pedig többségi külföldi tulajdonba került. A kétezres években, többek között az új bázeli tőkeszabályok hatására, megkezdődött a takarékszövetkezeti integráció megerősítése, ám az integrációs törvényt többszöri nekifutásra sem sikerült az európai normákkal összhangba hozni, a létrejött integrációs csoportosulások nem feleltek meg az európai szabályozási követelmények szerinti erős integrációnak, ami a szektor súlyos tőkehiányát jelezte. A többszörösen felpuhult, korábbi integrációs törvény nagyon laza integrációk létrejöttét is lehetővé tette, így a szektorban kezdetben két, majd három, végül négy különbözö, „integrációnak” nevezett csoportosulás is létrejött. ${ }^{35} \mathrm{~A}$ devizahitel-válság ugyan elkerülte a szektort, de a válság alatt így is több takarékszövetkezet helyzete megrendült, évente több takarékszövetkezeti csőd, avagy csődöt megelőző összeolvadás is bekövetkezett.

A válság után az európai mércével mérve is egységes és erös integrációt létrehozó 2013. évi integrációs törvényt érdemi előkészitő vita és hatástanulmányok nélkül fogadta el az országgyülés. A törvény tartalmazta, hogy egyetlen integráció létezhet csak, a régi integrációk ebbe olvadnak be. Az integrációt közös üzletpolitika, egységes termékek, egységes informatikai rendszer jellemzi. Az integrációs szervezetet (Szövetkezeti Hitelintézetek Integrációs Szervezete, SZHISZ) az integrációs törvény rendkívül erös beavatkozási és döntési jogkörrel ruházta fel. A törvény minden takarékszövetkezetnek, sőt minden korábban bankká alakult, de integrációs tagként tevékenykedő intézménynek is előírta a kötelező a tagságot. Kötelezte a takarékszövetkezeteket a belépéssel egy új alapszabály elfogadására, ami addigi döntési önállóságukat és a Takarékbankban gyakorolt tulajdonosi jogosítványaikat

\footnotetext{
${ }^{35}$ Országos Takarékszövetkezeti Intézményvédelmi Alap (Otiva): a legtöbb takarékszövetkezetet tömörítő, a Takarékbankkal mint központi bankkal rendelkező formáció. Takarékszövetkezeti Intézményvédelmi Alap (Takiva): az 1993-as állami konszolidációból kimaradt, méretében gyakorlatilag a legnagyobb 10-12 takarékszövetkezet csoportja. Regionális Pénzintézetek Intézményvédelmi Alapja (Repiva): 2010-ben született integráció a Buda-Cash érdekeltségébe tartozó hat jelentős méretű - korábban Otivába vagy Takivába tartozó, illetve integráción kívüli - takarékszövetkezetből létrejött formáció, a későbbi DRB bankcsoport elődje. Hitelszövetkezetek Első Hazai Önkéntes Betétbiztosítási és Intézményvédelmi Alapja (HBA): a hitelszövetkezeteket és a Széchenyi Bankot tömörítő csoport.
} 
korlátozta. Az integráción belül megkezdődött egy erős tisztítás és centralizálás, ennek keretében például 2015 augusztusában tíz jelentős méretű dunántúli takarékszövetkezet mondta ki az egyesülést, amihez hasonló fúzió korábban nem volt a szektorban. A tendenciák ismeretében további nagy létszámú fúziókra és erőteljes centralizációra számíthatunk a jövőben is.

Külön törvény értelmében 136 milliárd forint állami tőkejuttatással jött létre a Szövetkezeti Hitelintézetek Integrációs Alapja (2013. évi CLVI. törvény). ${ }^{36} \mathrm{Ez}$ az összeg nagyságrendileg megegyezett valamennyi takarékszövetkezet akkori saját tőkéjének összegével (2013. évi Aranykönyv), tehát rendkívül erős tőkebázist jelentett. Az Alap egyetlen célja a SZHISZ számára vagyon rendelkezésre bocsátása, amivel a takarékszövetkezeti szektor tőkehiánya jó időre megoldódott.

Az integráció központi bankjaként a törvény a Takarékbankot nevezte meg. A Takarékbank többségi tulajdonosa azonban - mint ezt már tárgyaltuk - a tranzitállamosítást követően az FHB Bank által dominált befektetői csoport lett. ${ }^{37} \mathrm{Az}$ FHB Bank, amely a támogatott lakáshitelek és a devizahitelek révén a válság elött a lakossági hitelpiac nagyjából 4 százalékát jelentette, a válságot követően több meghatározó stratégiai lépést valósított meg:

- 2010-ben stratégiai együttmüködést alakított ki az Allianz Bankkal, majd 2011-ben magába is olvasztotta a bankot, ezzel bővítette termékpalettáját és fiókhálózatát;

- 2013 júliusában stratégiai szövetségre lépett a Magyar Postával. Az együttmüködés keretében a postákon megjelentek az FHB termékei, a két cég közösen szerezte meg a Díjbeszedő Holdingot, és együtt építették ki a Posta befektetési szolgáltatását.

Az FHB Csoport-Posta-takarékszövetkezeti integráció konglomerátum egyre több ponton kapcsolódott egymáshoz, amit több kereszttulajdonlási lépés erősített meg:

- 2013 októberében az integráció csúcsszerve, a SZHISZ 25 százalék mínusz 1 szavazatnyi tulajdont szerzett a Magyar Postában;

- 2014. szeptember 29-én a Magyar Posta megvásárolta az FHB Kereskedelmi Bank 49 százalékát, majd ebből 8,21 százalékot 2015. július 8-án a Takarékbank Zrt. és öt takarékszövetkezet ${ }^{38}$ részére értékesített;

- 2015. szeptember 24-én az FHB belépett a takarékszövetkezeti integrációba, azaz a Szövetkezeti Hitelintézetek Integrációs Szervezete (a SZHISZ) felvette tagjai sorába az FHB Jelzálogbankot és a tulajdonában álló FHB Kereskedelmi Bankot.

\footnotetext{
${ }^{36}$ Az Alap tulajdonosa a Magyar Fejlesztési Bank, de nem vonhatja vissza az állami tőkejuttatást, és nem szüntetheti meg az Alapot.

${ }^{37}$ 1997-ben alapították a többségi állami tulajdonban lévő Földhitel- és Jelzálogbankot (FHB). Eredetileg csak a Jelzálogbank tartozott a csoporthoz, később megalapították az FHB Kereskedelmi Bankot, így jött létre az FHB Csoport. 2003-ban vezették be a Budapesti Értéktőzsdére, amivel párhuzamosan az állam részesedése 53,2 százalékra csökkent, majd 2007 harmadik negyedévében az állam szinte teljes mértékben értékesítette maradék részvénypakettjét és kisebbségi tulajdonos maradt. Az FHB Csoport legnagyobb tulajdonosa az A64 Vagyonkezelő Kft. és a Vienna Capital Partners (VCP) lett. Az A64 Vagyonkezelő Kft. mögött Spéder Zoltán, a Vienna Capital Partners (VCP) mögött Heinrich Pecina áll. Mindkét cég tulajdonrésze nagyjából 15-15 százalék (2015. december 31-i állapot).

${ }^{38}$ Hajdú Takarék, Kápolnásnyék és Vidéke Takarékszövetkezet, Sárbogárd és Vidéke Takarékszövetkezet, Szentgál és Vidéke Takarékszövetkezet és a Veresegyház és Vidéke Takarékszövetkezet.
} 
Az FHB igazgatóságának javaslatára 2015. december 28-án a társaság alaptőkéjét 4,2 milliárd forinttal megemelték. ${ }^{39} \mathrm{Az}$ új, részben osztalékelsőbbségi részvényeket teljes egészében a Takarékbank és 30 integrált takarékszövetkezet jegyezte le, így együttes tulajdonrészük 39,2 százalékra nőtt az FHB-ban. Az A64 és a VCP együttes tulajdonrésze így 29,6 százalékra csökkent, azonban még mindig irányító szerepben maradtak, mivel az új tulajdonosok szavazó részvényeinek aránya 26,1 százalék lett.

Mindezen lépések eredményeként az FHB szoros kereszttulajdonlásban dolgozik együtt a Magyar Postával, kontrollálja a Díjbeszedő Holdingot és gyakorlatilag a takarékszövetkezeti integráció egészét is. A Spéder Zoltán irányította, a válság idején még tőkeproblémákkal küszködő FHB Csoport az integráció (takarékszövetkezetek, kisbankok, Takarékbank)-Posta-Díjbeszedő konglomerátum révén mára Magyarország második legerösebb, a piac közel 10 százalékot kontrolláló pénzügyi szolgáltatója lett. ${ }^{40} \mathrm{Az}$ integráció tőkeerejét nem tagjai és tulajdonosai jelentik, hanem az Integrációs Alapban elhelyezett 135 milliárd állami pénz, ami a további várható átalakítások során az integráció szavatoló tőkéjét növelő vagyonként lesz beszámítható a takarékszövetkezetek, a Takarékbank és az FHB Csoport müködéséhez (4. ábra).

4. ábra

Az FHB és a takarékszövetkezeti integráció tulajdonosi összefonódásai, 2015. december 31.

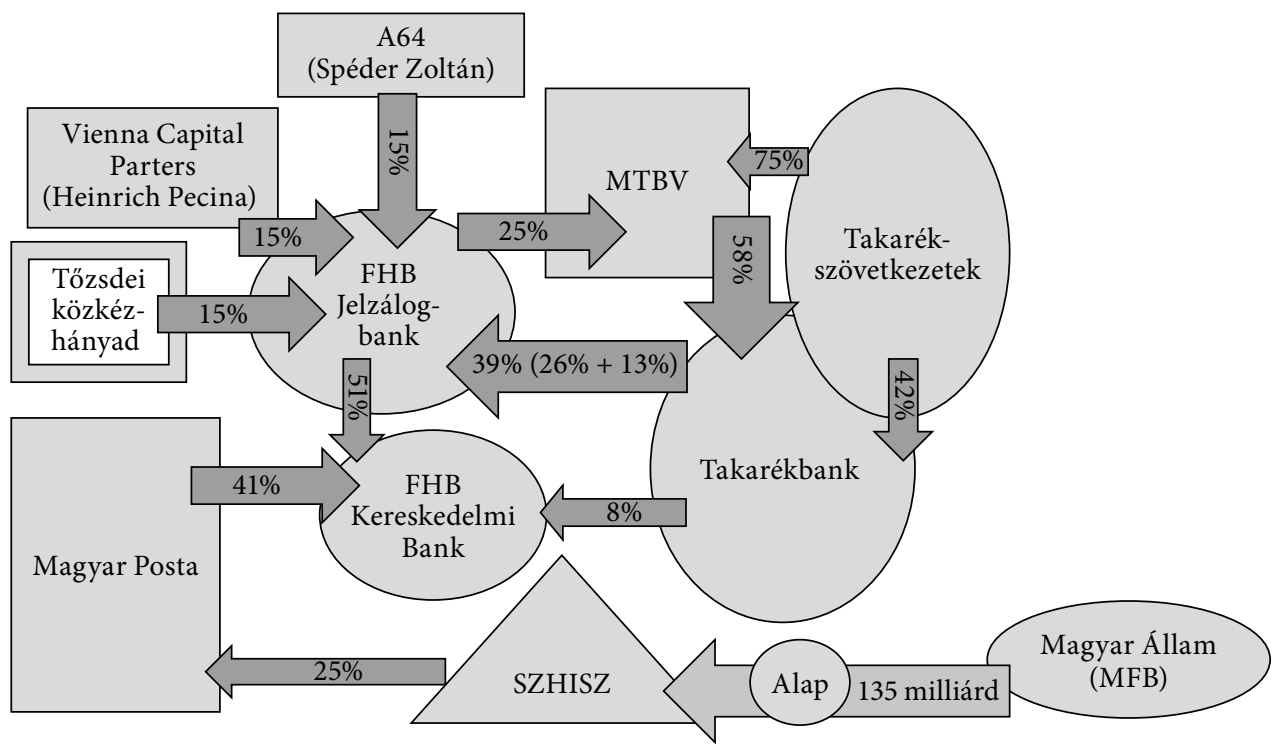

Forrás: saját szerkesztés.

${ }^{39}$ Az FHB rendkívüli nyilvános tájékoztatója a BÉT hivatalos oldalán jelent meg 2015. december 30án, http://bet.hu/newkibdata/120461728/FHB_Nyrt rendk_v_li_k_zlem_ny_20151230.pdf.

${ }^{40}$ Kiváló áttekintést ad a csoport egészének megváltozott helyzetéröl a Portfolio 2015. december végi elemzése: http://www.portfolio.hu/finanszirozas/bankok/beszallnak_a_takarekok_az_fhbba.1.224762.html. 
A leírtak alapján a közösségi tulajdon gyakorlatilag megszűnt, és állami tőke felhasználásával magántulajdonba került a korábbi takarékszövetkezeteknél ma már sokkal szélesebb pénzügyi szolgáltató kört tartalmazó integráció. Önmagában az erős integráció létrejötte a takarékszövetkezeti szektor válsággal szembeni ellenálló képessége növeli, ám egy gyenge tökehátterü magántulajdonosi csoport dominanciája gyengíti ezt. ${ }^{41}$

\section{Belföldi, szűk tulajdonosi hátterü bankok}

A szük tulajdonosi hátterü, belföldi kisbankok empirikus elemzésére nemigen lehet nemzetközi példát találni csekély számosságuk és elhanyagolható szerepük miatt. Magyarországon a kilencvenes években a bankpiac majdnem 10 százalékát tették ki, majd szinte kivétel nélkül csődbe jutottak, vagy csőd előtt felvásárolták őket. A kétezres években ilyen típusú bankok meg sem jelentek a magyar piacon. A válság alatt néhány régióbeli példát ismerünk, ahol a talpon maradt külföldi tulajdonú bankok mellöl a csekély tőkeerejü, szük tulajdonosi hátterü belföldi bankok jutottak csődbe. Magyarországon 2010 után a külföldi bankok kiszorításával párhuzamosan megkezdödött egyes, szük tulajdonosi körrel rendelkezö belföldi bankok „helyzetbe hozása”. A bankok piaci súlya ma még elhanyagolható, csekély tőkeerejük sem a stabilitás biztosítékát jelenti, egyes képviselőik már az elmúlt néhány évben csődbe jutottak (DRB bankcsoport, Széchenyi Bank, Quaestor Bank).

A privatizációs hatást vizsgáló, illetve az állami versus magántulajdont elemző tanulmányok közül csak nagyon kevés van, amelyik a magántulajdon strukturális jellemzőinek hatását is elemezné. Az olyan többségi tulajdon ugyanis, amely sem nem közösségi, sem nem tőzsdei, sem nem állami, nem jellemzö Európa banki térképein. Barryés szerzőtársai [2011] 249 bankot vizsgált meg. Ebből mindössze 32-re volt igaz, hogy nem tőzsdei (szórt) tulajdonlás és nem banki vagy pénzügyi intézményi többségi tulajdonos jellemezte. Ebből a 32 bankból négy volt többségi családi tulajdonban és 28 vállalati tulajdonban. Az európai bankunió központilag felügyelt 100 bankcsoportja között 11 ilyen található, azonban ezek a 100 bank összesített mérlegföösszegének mindössze 2 százalékát teszik ki, és többségükben olyan nagyvállalatok, mint a Volkswagen-csoport, a Renault-csoport, az Axa-csoport stb. jelentik a tulajdonosi hátteret (Schoenmaker-Vernon [2016]).

Nemigen készültek olyan jelentős empirikus tanulmányok, amelyek a többségi vállalkozói vagy családi tulajdon hatékonyságra, stabilitásra gyakorolt hatását vizsgálták volna. Az eddigi tanulmányok egyaránt kimutatták az egy-egy tulajdonosi csoport (vállalat, család, menedzsment) általi tulajdonkoncentráció kockázatcsökkentő és kockázatnövelő hatását, a hatékonyság emelkedését és csökkenését. A bizonytalan eredmények abból is adódhatnak, hogy a banktulajdonlás szabályai országonként eltérők - gyakran a családi/magántulajdon pénzügyi intézményi

\footnotetext{
${ }^{41}$ A tanulmány leadását követően az országgyülés módosította az integrációs törvényt, ennek alapján akár jelentős változások is várhatók a tanulmányban leírtakhoz képest.
} 
befektető képében jelenik meg, ami az eredmények robusztusságát rontja. A vállalati tulajdon esetében nem mellékes, hogy a banküzem hátterét biztositó vállalat vagy vállalatcsoport mennyire tőkeerős: a General Electric vagy General Motors által saját ügyfélkör-finanszírozást biztosító bankról van szó, avagy egy kis tökeerejü vállalkozói csoport elsősorban saját finanszírozást megvalósító bankalapításáról. Az utóbbiak a kevésbé válságrezisztens formát jelentik.

A transzformációs válság idején, a kilencvenes években a régióban létrejött szük tulajdonosi hátterü kisbankok nem bizonyultak életképeseknek. Bonin és szerzőtársai [2004] a régióbeli privatizációt elemzésekor nemcsak azt vizsgálta, hogy a privatizáció hogyan járult hozzá a banki hatékonyság javulásához (jelentősen), hanem azt is, hogy a privatizáció utáni tulajdonos milyen hatással volt a bankra. A szerzők arra a következtetésre jutottak, hogy a belföldi magántulajdonosok, sok esetben vállalkozói csoportok által tulajdonolt bankok nem nyújtottak jobb teljesítményt, nem voltak hatékonyabbak, mint az állami bankok, mérhető pozitív változást a külföldi (szakmai) befektetők által tulajdonolt bankok esetében mértek. Ez a tanulmány azért jelentős, mert az egyetlen általunk ismert empirikus kelet-európai vizsgálat, amelyik a magántulajdonos milyenségét is elemezte.

Magyarországon is ezt a tendenciát figyelhettük meg: a rendszerváltást követö években nem voltak sokkal sikeresebbek a többségi belföldi állami tulajdonú vállalatok, illetve belföldi magántulajdonosi körök által tulajdonolt kis- és középbankok - „a belközép” - sem.

Ezeknek a kis- közepes bankoknak számos esetben volt valamilyen elötörténetük: többségükben a szocializmus utolsó éveiben létrehozott különböző innovációs, fejlesztési alapokból, pénzügyi egyesülésekből nőttek ki. A kétszintű bankrendszerbe való belépéskor e bankok tőkéje egy kisbank müködésének - az adott gazdasági környezetet is figyelembe véve - legfeljebb évi 10-15 százalékos növekedéséhez volt elegendö. Ezeknek a bankoknak az átlagos mérlegföösszege viszont 1988 és 1991 között éves átlagban 51 százalékkal nőtt. A bankmenedzsment legnagyobb gyengesége ezekben az esetekben nem az volt, hogy túl nagy kockázatot vállalt, hanem hogy nem tudta, hogy mekkorát vállal. Voltak olyan ügyfelek, akik a bank tulajdonosaihoz, menedzsmentjéhez „közel álltak”, és ezért jutottak hitelhez. Utólag nehezen ítélhető meg, hogy eleve magasabb kockázatot viseltek, vagy a körülmények szerencsétlen összejátszása okozta a hitel vissza nem fizetését. Voltak azonban olyan ügyfelek is, akik eleve tisztában voltak azzal, hogy nem lesznek képesek a hitel visszafizetésére („csalárd ügyfél”) - nem kevés ilyen eset került be a magyar bankkonszolidáció történetébe. És végül e csoporton belül volt a bank tulajdonosaihoz, illetve menedzsmentjéhez közel álló vállalkozói kör, amely esetében nem kizárt a „csalárd bankolás”, azaz, hogy a bank eleve ezen ügyfélkör részére játszotta át a betétesek pénzét. Ez a gyorsan bővülő portfólió egyre nagyobb hányadban vált nem termelő eszközzé, olyan hitellé, majd egyes esetekben hitelekből konvertált befektetéssé, amely már nem hozta, csak vitte a pénzt (Király [1995], [1999]).

Mindennek következtében ezek a bankok - amelyeknek egyesített mérlegföösszege a kilencvenes évek elején még a bankrendszer eszközeinek közel 9 százalékát 
5. ábra

Szűk tulajdonosi hátterü, belföldi magánbankok piaci súlya, 1988-2015

Százalék

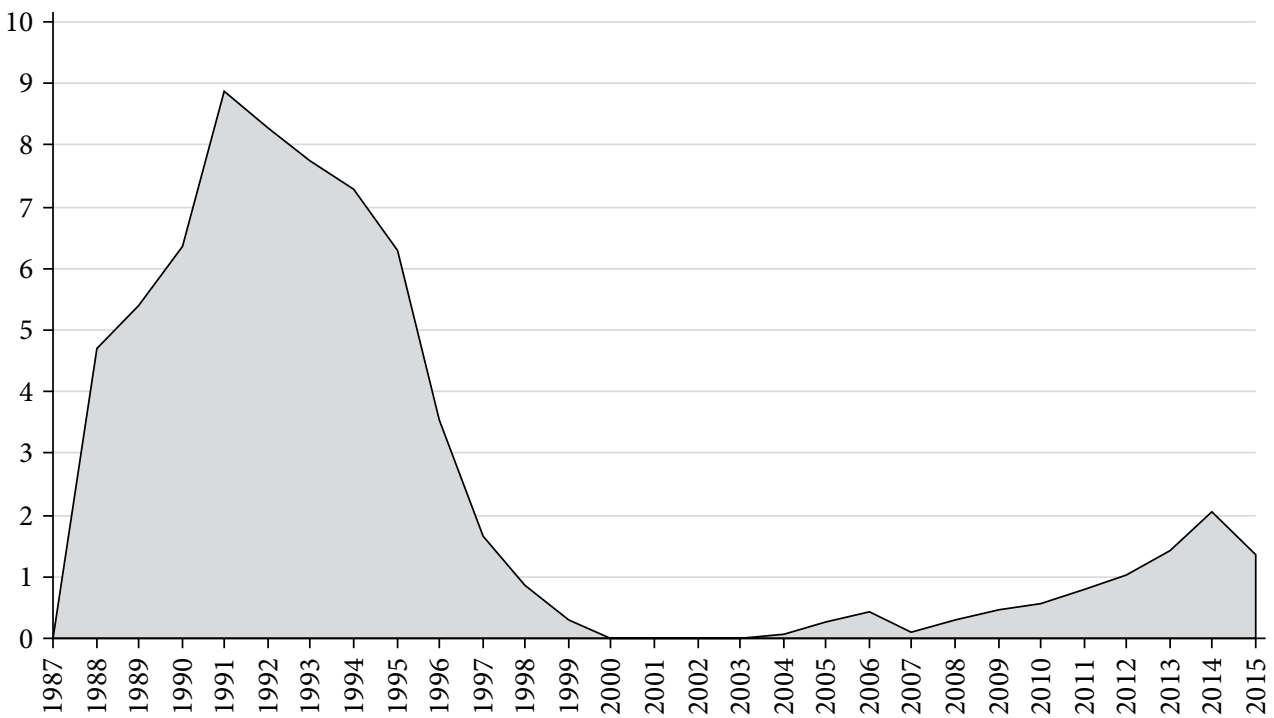

Megjegyzés: az FHB Csoportot az adatok nem tartalmazzák.

Forrás: 1988-2002: Pénzügyi Almanach, 2003-2015: Aranykönyv, saját számítások.

adta - a kétezres évek fordulójára szinte kivétel nélkül eltűntek a magyar piacról: többségük tönkrement, avagy a tönkremenést megelözően beolvadt egy nagyobb bankba (Függelék F3. táblázat). Az 5. ábrán látható, hogy a kétezres évek elejéig piaci súlyuk gyakorlatilag zéró volt.

A többségi külföldi tulajdonnal jellemezhető régióbeli országokban a válság alatt csak elvétve kellett bankok megmentésére adófizetői pénzt felhasználni, s éppen a hazai, szűk magántulajdonosi hátterű bankok esetében. Lettországban 2008 novemberében az állam vette át a csődbe ment Parex Bankot, ${ }^{42}$ amely abban az időben az ország második legnagyobb magánbankja volt. A litván gyökerü Snorasbankcsoport ${ }^{43} 2011$ novemberében jutott csődbe, és került állami konszolidációba, magával rántva a lett Krajbankát ${ }^{44}$ (a korábbi postai takarékbankot) is. 2013 májusában a litván Ūkio ${ }^{45}$ bankot államosították a csődöt követően. Bulgáriában 2014 júliusában a negyedik legnagyobb bolgár bankot, a Corpbankot ${ }^{46}$ rohanták meg a betétesek, majd közel egy év elteltével a bankot az állam szanálásba vette.

${ }^{42}$ A többségi tulajdonosok (Valērijs Kargins és Viktors Krasovickis) a részvénytőke 84,83 százalékát birtokolták.

${ }^{43}$ A Snoras Bank tőzsdei cég volt, azonban többségi tulajdonosai magánszemélyek voltak: az orosz Vladimir Antonov a részvények 67 százalékát, a lett Raimondas Baranauskas 25 százalékát birtokolta.

${ }^{44}$ A Krajbank tőzsdén jegyzett társaság volt, azonban a többségi tulajdonos a Snoras Bank (53,2 százalék), illetve közvetlenül Vladimir Antonov (32 százalék) volt.

${ }^{45}$ Az Ükio Bank több mint 50 százalékos tulajdonosa Vladimir Romanov volt.

${ }^{46}$ A Corpbank (Corporate Commercial Bank) tőzsdén jegyzett cég volt, de a részvények többségét egy bolgár üzletember Tsvetan Vasilev tulajdonolta. 
Ugyanezekben az országokban a külföldi tulajdonú bankok válságellenállók voltak - mind a Baltikumban, mind a Balkánon a tulajdonosok tőkével és forrással is ellátták leánybankjaikat. E néhány régióbeli eset arra utal, hogy a szük hazai tulajdonosi körrel jellemezhetö bankok mérettöl függetlenül kevésbé voltak rezisztensek a válsággal szemben, mint a többségi külföldi tulajdonú bankok, ahol az anyabankok forrással és tőkével is leánybankjuk mögött álltak.

Magyarországon a szűk tulajdonosi hátterű magyar magánbankok válság alatti ellenálló képessége tehát nem megfigyelhetö, mivel gyakorlatilag nem léteztek ilyen bankok. ${ }^{47} \mathrm{~A}$ válságot követően azonban már hat frissen alakult ilyen típusú bank is bajba került: 2014-ben a Széchenyi Bank, 2015-ben a Buda-Cash-csoporthoz tartozó DRB-bankcsoport négy tagja, valamint a Quaestor Bank. ${ }^{48}$

A 2. ábrán láttuk, hogy a válság után, a külföldi bankok kiszorítását követően a belföldi tulajdonú bankok piaci részesedése erőteljes növekedésnek indult: nőtt az állami bankok súlya, nőtt az OTP Csoport részesedése, nőtt az FHB vezette integrációs szervezetet piaci súlya, és teret nyertek a kisebb belföldi tulajdonú magánbankok is. Ez utóbbi csoport egyedi és összesített piaci súlya még mindig elhanyagolható (5. ábra), de egyes tagjait az állam különböző eszközökkel igyekszik helyzetbe hozni.

DUNA TAKARÉK • A takarékszövetkezeti integrációs törvénynek a korábban említett furcsaságok (államosítás és az intézmények döntési jogkörének erőteljes korlátozása) mellett volt még egy különlegessége: meghatározta a „folyamatban lévő engedélykérelemmel rendelkező hitelintézet" fogalmát, ${ }^{49}$ és ezekre a bankokra nem írt elő integrációs kötelezettséget. A nyolc, akkor engedélyért jelentkező takarékszövetkezet közül hat mára már elvesztette müködési engedélyét (Függelék F4. táblázat), ${ }^{50}$ az életben maradottak egyike a Garancsi István vállalkozói csoportjához köthetö Duna Takarék Bank. ${ }^{51}$ A Duna Takarék Bank a volt takarékszövetkezetek között nagynak számított 70 milliárd forintnál valamivel nagyobb mérlegföösszegével, de ez a hitelintézeti szektor mérlegföösszegének mindössze 0,25 százaléka, nagyjából egy nagybank fiókméretének felel meg.

GRÁNIT BANK • A hányattatott elöéletü többségi magántulajdonú bankban 2013-ban, mint az a korábbiakból már kiderült, a Magyar Állam üzleti céllal 49

${ }^{47}$ Az FHB Bank tőkeproblémáit már tárgyaltuk, az Ella Bankot a válság előtt vásárolta fel az Axa-csoport.

${ }^{48}$ A Quaestor Bank még nem kezdte meg működését a Quaestor-csoport összeomlásakor, így a bank felszámolási vagyonba került és privatizáció alatt áll.

${ }^{49}$ „Folyamatban lévő engedélykérelemmel rendelkező hitelintézet: jelen törvény elfogadásáig a nem takarékszövetkezeti hitelintézetté alakulás iránt a Felügyeletnek kérelmet benyújtott szövetkezeti hitelintézet, amely 2013. december 31-ig a Felügyelet engedélye alapján nem takarékszövetkezeti hitelintézetté alakult és e törvény hatálybalépését követő 100 napon belül már nem tagja az Integrációs Szervezetnek" (2013. évi CXXXV. törvényintegrációs törvény).

${ }^{50}$ Akik elvesztették müködési engedélyüket, illetve felszámolás alatt állnak: Körmend és Vidéke Takarékszövetkezet, a DRB-bankcsoport négy kisbankja és a Széchenyi Bank. A Duna Takarék Bank Zrt.-n kívül egyedül mủködő takarékszövetkezetből alakult kisbank a Polgári Bank, amelyik nem keverendő össze a kilencvenes években működő és megszűnő Polgári Bankkal.

${ }^{51}$ A Halászi és Vidéke Takarékszövetkezet korábbi elnöke (Illés Zoltán) és a Duna Takarékszövetkezet korábbi elnöke (Garancsi István) nagyjából egyenlő arányban, 14-14 százalékban tulajdonos. 
százalékos részesedést szerzett. ${ }^{52} \mathrm{~A}$ bank a növekedési hitelprogramnak piaci súlyánál jelentősebb szereplője.

NöveKedÉsi HitelBANK ${ }^{53}$ • A Magyar Nemzeti Bank kisvállalkozásokat támogató programjáról elnevezett bank egyelöre az indulás stádiumában van, a növekedési hitelprogramnak azonban piaci súlyánál jelentősebb szereplője.

A szűk tulajdonosi hátterű bankokról kevés nemzetközi tanulmány, empirikus információ áll rendelkezésre. A hozzáférhető egyedi esettanulmányok azt mutatják, hogy a régióban ezek a bankok gyenge tőkehátterük miatt sem a transzformációs, sem a nagy pénzügyi válság idején nem voltak igazán rezisztensek. Magyarországon a transzformációs válság alatt ezek a bankok mind eltűntek a bankpiacról. A jelenlegi tulajdonszerkezet-átalakítás során az állam támogatja az új piacra lépő szűk tulajdonosi hátterű kisbankokat, ám az elmúlt öt év válságmentes időszakában az új kisbankok több mint fele már a felszámolás sorsára jutott. Megítélésünk szerint e bankok szűk, nem tőkeerős tulajdonosi háttere nem járul hozzá a pénzügyi stabilitás fokozásához.

\section{Összefoglalás}

A tanulmány a magyar bankrendszer elmúlt mintegy harminc évének történetét tekinti át a tulajdonosi struktúra és a sokktürő képesség alakulásának szempontjából. Míg a 2008-as válság kirobbanása meglehetősen stabil állapotban érte a bankrendszert, a 2010 után elindult átalakulások ezzel ellentétes irányba mutatnak, miközben az átalakítás mellett felhozott érvek elméleti és empirikus igazolása erősen kérdéses.

A magyar bankrendszerben az elmúlt néhány évben

- megnőtt az üzleti célú állami banktulajdon aránya;

${ }^{52}$ A Gránit Bank legrégebbi elődje az 1985-ben először szakosított pénzintézetként létrehozott, majd bankká alakult Âltalános Vállalkozási Bank volt, amely nemcsak felelőtlenül folyósított vállalkozói hiteleket, hanem egy kétes váltóügyletbe is belekeveredett (mint az első magyar bankbotrány, az Ybl Bank csődjének egyik szereplője és az Ybl Bank által 20 százalékban tulajdonolt pénzintézet). Ebben a csőd előtti helyzetben vásárolta fel a bankot 1992-ben a német WestLB és müködtette sikeresen kis méretü „butikbankként” 2009-ig. Az állami tulajdonú anyabank a pénzügyi válság során súlyos veszteségeket szenvedett, majd meg is szünt. A bankot 2010 januárjában felvásárolta a Wallis Zrt., amelyik fél éven belül, 2010 májusában továbbadta a Demján Sándor érdekkörébe tartozó Magyar Töketársaság Zrt.-nek. 2015-ben módosult a tulajdonosi szerkezet: a Magyar Tőketársaság részesedését a vezérigazgató, Hegedűs Éva érdekkörébe tartozó E. P. M Tanácsadó Kft. vette meg.

${ }^{53}$ Az NHB őse, az 1990-ben alakult Kultúrbank külföldi tulajdonosairól mindvégig feltételezték, hogy végső soron Boros Imre és Töröcskei István állnak mögöttük. Boros és Töröcskei egyben a Kultúrbank vezetői is voltak abban az időben (http://www.ma.hu/tart/rcikk/a/0/13404/1). A bankot az összeomlás előtt 1992-ben vásárolta fel a francia Indosuez Bank, ám már 1996-ban továbbadta az európai uniós banklicencet kereső dél-koreai Hanwha Banknak. A Hanwha Bank kis méretű speciális igényeket kielégítő (niche) bankként közel másfél évtizeden keresztül maradt Magyarországon, majd 2013 novemberében kivonult a magyar piacról, és a bankban többségi tulajdont szerzett az Evopro Finance Zrt., az addig inkább elektromos buszok gyártásával foglalkozó Evopro-csoport tagja. 2014. novemberben már a Szemerey Tamás üzleti csoportjához tartozó BanKonzult Kft. lett a bank 98,5 százalékos tulajdonosa és a bank egyben nevet is váltott. 
- háttérbe szorultak a külföldi bankok, ezen belül is felerösödött a fiókosodás;

- megerősödött az állami tőkejuttatásban részesülő, ám meghatározóan magántulajdonba került takarékszövetkezeti integráció;

- piacot nyertek a kis, jelentős tőkeháttér nélküli, belföldi vállalkozói csoportokhoz, illetve magánszemélyekhez köthető bankok.

Mindezek a tendenciák - a tulajdonosi szerkezet átalakulása - a korábbinál gyengébb válságellenálló képességre utalnak. Az állami tulajdon kevésbé válságellenálló, mint a magántulajdon: ezt támasztja alá a transzformációs válság állami bankjainak sorsa és a jelenlegi pénzügyi válság számos példája. A magyar állam válságot követő üzleti célú banki tulajdonszerzése eddig nem igazolta az ellenkező várakozásokat, egy bank már csődbe jutott, egy másikat szanálás alá kellett venni.

A külföldi bankok - földrajzi közelséget is kiaknázó, üzleti modelljükben az uniós csatlakozásra építő - tulajdonszerzése a régióbeli gazdaságokban inkább pozitív eredményeket hozott. Nem bizonyítható, hogy a belföldi bankoknál nagyobb felelősségük lenne a külföldi bankoknak a válságot megelőző (deviza)hitelboom kialakulásában és a válságot követő hitelvisszafogásban. A külföldi tulajdon a válság alatt ütésállónak bizonyult: a külföldi tulajdonosok forrással és tőkével is biztosították leánybankjaik működését. A válságot követően Magyarországon megkezdődött lassú kiszorításuk, ami piaci súlyuk csökkenésében is kimutatható. Az egyik jelentős piacnyerő csoport a magántulajdonba került takarékszövetkezeti integráció, amelynek kialakulását törvények és állami tőkejuttatás segítették. A másik feltörekvő csoport a ma még elhanyagolható piaci súlyú és a szük belföldi tulajdonosi hátterű, kisbankok csoportja, amelyek helyzetbe jutását szintén állami lépések segítik. A kilencvenes évek elejének válságával szemben a hasonló tulajdonosi szerkezetü belföldi magántulajdonú bankszektor nem bizonyult ellenálló képesnek, az ilyen típusú bankok eltűntek a magyar bankpiacról. A régióbeli hasonló bankok közül számos jutott csődbe a válság idején.

A megfigyelhető állam által támogatott piaci átrendeződés határozottan egy irányba mutat: a többségi magyar tulajdonú, kevés számú közép- és nagybankot tartalmazó bankrendszer irányába. Az új banktulajdonosi réteg több szereplője már korábban megjelent a hitelintézeti szektorban, a végleges tulajdonosi struktúra körvonalai azonban jelenleg még homályosak. A magyar bankrendszer átalakítása még folyamatban van, a végső képet nagyjából két-három év múlva fogjuk látni, az új struktúra piaci és gazdasági hatásait pedig csak középtávon, öt-nyolc év távlatában lehet majd értékelni.

A kérdés azonban fölöttünk lebeg: a külföldi tulajdonosok kiszorításával, az állam üzleti szerepvállalásával és az állam által támogatott új tulajdonosréteg helyzetbe hozásával vajon valóban egy „biztonságosabb, hazai tőkére alapozott, hosszú távon fenntartható" pénzügyi szektor jön létre, avagy a 20 évvel ezelőtti, számos csőddel és bankkonszolidációval tüzdelt történet ismétlődik meg? 


\section{Hivatkozások}

ÁBel IstváN-SzaKadÁt LÁszló [1997]: A bankrendszer alakulása Magyarországon 19871996 között. Közgazdasági Szemle, 44. évf. 7-8. sz. 635-652. o.

Andrianova, S.-Demetriades, P.-Shortland, A. [2010]: Is Government Ownership of Banks Really Harmful to Growth? DIW Discussion Paper, 987. https://www.diw.de/ documents/publikationen/73/diw_01.c.354939.de/dp987.pdf.

Avdjiev, S.-Kuti Zsolt-Takáts Előd ([2012]: The euro area crisis and cross-border bank lending to emerging markets. BIS Quarterly Review, december, 37-47. o. www.bis.org/ publ/qtrpdf/r_qt1212f.pdf.

BALOGH IMre [2015]: Pénzügyi válságkezelés, bankrehabilitáció és a problémás hitelek rendezése: magyar és szlovén megoldások regionális és európai kontextusban. $\mathrm{PhD}$-értekezés, Debrecen, https://dea.lib.unideb.hu/dea/bitstream/handle/2437/219179/Balogh_I_ ertekezes.pdf?sequence $=1$ \&isAllowed $=\mathrm{y}$.

BANAi ÁdÁM-Király Júlia-Nagy Márton [2010]: Az aranykor vége Magyarországon. Külföldi szakmai és lokális tulajdonú bankok - válság előtt és válság után. Közgazdasági Szemle, 57. évf. 2. sz. 105-131. o.

BANAi ÁDÁM-KirÁly Júlia-VÁRHEgyi Éva [2010]: A rendszerváltás 20 évének egy egyedi fejezete: külföldi bankok dominanciája a kelet-közép-európai régióban, különös tekintettek Magyarországra. MNB-tanulmányok, 89. október http://mek.oszk.hu/12100/12167/12167.pdf.

BArry, T. A.-Lepetit, L.-TARAZI, A. [2011]: Ownership structure and risk in publicly held and privately owned bank. Journal of Banking and Finance, Vol. 35. No. 5. 1327-1340. o. http://dx.doi.org/10.1016/j.jbankfin.2010.10.004.

Beckmann, E.-Roitner, A.-Stix, H. [2015]: A Local or a Foreign Currency Loan? Evidence on the Role of Loan Characteristics, Preferences of Households and the Effect of Foreign Banks. Focus on European Economic Integration, Q1/15. Oesterreichische Nationalbank, 24-48. o. https://www.oenb.at/dam/jcr:63a9a6f8-8edf-4837-adca-e66787cfa31f/feei_2015_ q1_studies_beckmann.pdf.

Birchall, J.-Ketilson, L. H. [2009]: Resilience of the Cooperative Business Model in Times of Crisis. International Labour Office, Sustainable Enterprise Programme. ILO, Genf, http://storre.stir.ac.uk/bitstream/1893/3255/1/Resilience $\% 20$ of $\% 20$ the $\% 20$ Cooperative $\%$ 20Business\%20Model\%20in\%20Times\%20of\%20Crisis.pdf.

Bonin, J. P.-HASAN, I.-WACHTEL, P. [2005]: Bank performance, efficiency and ownership in transition countries. Journal of Banking and Finance, Vol. 29. No. 1.31-54. o. http://dx.doi. org/10.1016/j.jbankfin.2004.06.015.

Brown, M.-HAAs, R. De [2010]: Foreign currency lending in Emerging Europe: Bank-level evidence. EBRD Working Paper, No. 122. http://www.ebrd.com/downloads/research/ economics/workingpapers/wp0122.pdf.

Cerutti, E.-Dell'Ariccia, G.-Pería, M. S. M. [2007]: How banks go abroad: Branches or subsidiaries? Journal of Banking and Finance, Vol. 31. No. 6. 1669-1692. o. http://dx.doi. org/10.1016/j.jbankfin.2006.11.005.

Cetorelli, N.-Goldberg, L. [2009]: Globalized banks: Lending to Emerging Markets in the Crisis. Federal Reserve Bank of New York, Staff Report, No. 377. https://www.newyorkfed. org/medialibrary/media/research/staff_reports/sr377.pdf.

Chen, G.-Wu, Y. [2014]: Bank Ownership and Credit Growth in Emerging Markets During and After the 2008-09 Financial Crisis. A Cross-Regional Comparison, IMF WP 14/171. https://www.imf.org/external/pubs/ft/wp/2014/wp14171.pdf. 
Claessens, S.-Jansen, M. (szerk.) [2000]: The Internationalization of Financial Services Issues and Lessons for Developing Countries. Kluwer Law International, The Hague Hardbound, $480 \mathrm{o}$.

Claessens, S.-Van Horen, N. [2014]: Foreign banks: Trends and impact. Journal of Money, Credit and Banking, Vol. 46. No. 1. 295-326. o. http://dx.doi.org/10.1111/jmcb.12092.

De HaAs, R. [2009]: In defence of foreign banks. VoxEU, CEPR's policy portal - május 28. http://voxeu.org/article/defence-foreign-banks.

De HaAs, R.-Korniyenko, Y.-Loukoianova, E.-Pivovarsky, A. [2012]: Foreign Banks and the Vienna Initiative: Turning Sinners into Saints? IMF Working Paper, 2012/117. http:// dx.doi.org/10.5089/9781475503463.001.

De HaAs, R.-Lelyveld, I. [2010]: Internal Capital Markets and Lending by Multinational Bank Subsidiaries. Journal of Financial Intermediation, Vol. 19. No. 1. 1-25. o. http://dx.doi. org/10.1016/j.jfi.2009.02.001.

Fiechter, J.-ÖtKer-Robe, I.-Ilyina, A.-Hsu, M.-SAntos, A.-Surti, J. [2011]: Subsidiaries or Branches: Does One Size Fit All? IMF, Staff Discussion Note, SDN/11/04. http://dx.doi. org/10.5089/9781455288564.006.

GÁL Zoltán [2012]: A hazai takarékszövetkezeti szektor szerepe a vidék finanszírozásában. Területi Statisztika, 15. (52.). évf. 5. sz. 437-460. o.

GÁl Zoltán-Burger Csaba [2013]: A vidék bankjai? A magyar takarékszövetkezeti szektor hitelezési aktivitása. Közgazdasági Szemle, 60. évf. 4. sz. 373-401. o.

GáRDOS IsTVÁN [2014]: Néhány gondolat a devizahiteles elszámolási törvényről. Gazdaság és Pénzügy, 1. sz. 52-65. o. http://www.gfmt.hu/cikkek/nehany-gondolat-a-devizahiteleselszamolasi-torvernyrol.php?kid=3\&did=259.

GÁRDOs István [2015]: Jog, jogértelmezés - gondolatok a devizahiteles törvények kapcsán. Jogtudományi Közlöny, 70. évf. 4. sz. 193-205. o.

Goldberg, I. [2007]: Financial Sector FDI and Host Countries: New and Old Lessons. FRBNY Economic Policy Review, Vol. 13. No. 1. https://www.newyorkfed.org/medialibrary/media/ research/epr/07v13n1/0703gold.pdf.

Goldberg, I. [2009]: Understanding Banking Sector Globalization. International Monetary Fund Staff Papers, Vol. 56. No. 1. 171-197. o. http://dx.doi.org/10.1057/imfsp.2008.31.

Groeneveld, H.-Vries, B. DE [2009]: European Co-operative Banks: First Lessons of the Subprime Crisis. Rabobank, http://www.globalcube.net/clients/eacb/content/medias/publications/ external_studies/Cb_first_lessons_financial_crisis_Rabobank_2009.pdf.

Hainz, C.-Hakenes, H. [2012]: The politician and his banker. How to efficiently grant state aid. Journal of Public Economics, Vol. 96. No. 1-2. 218-225. o. http://dx.doi.org/10.1016/j. jpubeco.2011.09.005.

HaVRYlChy , O.-JURZYK, E. [2011]: Inherited or earned? Performance of foreign banks in Central and Eastern Europe. Journal of Banking and Finance, Vol. 35 No. 5. 1291-1302. o. http://dx.doi.org/10.1016/j.jbankfin.2010.10.007.

KIRÁLY JúLIA [1995]: Válságspirál, avagy a magyar bankok tőkevesztésének egy lehetséges értelmezése. Közgazdasági Szemle, 42. évf. 9. sz. 819-837. o.

KIRÁLY JÚLIA [1999]: „Belközép” bankok működése és bukása. Világgazdaság, január 18.

KIRÁLy JúliA [2005]: Egy bank, amely közel áll Önhöz. A Postabank privatizációjának története 2002-2003, ÁPV Rt., Budapest.

KorNAI JánOs [2015]: U-kanyar Magyarországon. Élet és Irodalom, április 3. 8-10. o. Angolul: Hungary's U-Turn. Capitalism and Society, Vol. 10. No. 1. 2. cikk. http://ssrn.com/ abstract $=2629592$. 
Körner, T.-Schnabel, I. [2010]: Public Ownership of Banks and Economic Growth. The Role of Heterogeneity. Preprints of the Max Planck Institute for Research on Collective Goods, Bonn 2010/41. https://www.coll.mpg.de/pdf_dat/2010_41online.pdf.

La Porta, R.-Lopez-De-Silanes, F.-Shleifer, A. [2002]: Government Ownership of Banks. The Journal of Finance, Vol. 57. No. 1. 265-301. o. http://dx.doi.org/10.1111/15406261.00422 .

Lahnsteiner, M. [2013]: Private Sector Debt in CESEE EU Member States. Focus on European Economic Integration, Q3/13. Österreichische Nationalbank, 30-47. o. https:// www.oenb.at/dam/jcr:aadceab2-7495-4676-ab61-15a28d60cedf/feei_2013_q3_studies_ lahnsteiner_tcm16-257384.pdf.

LANGMÁR FerenC-PAPp EMília [1996]: Bankkonszolidáció: körhitel. Magyar Narancs, 37. sz. szeptember 12. http://magyarnarancs.hu/belpol/bankkonszolidacio_korhitel-61912.

LiIKanen, E. (szerk.) [2012]: High-level Expert Group on reforming the structure of the EU banking sector. Final Report, Brüsszel, október 2. http://ec.europa.eu/finance/bank/docs/ high-level_expert_group/report_en.pdf.

Majnoni, G.-Shankar, R.-VArhegyi, E. [2003]: The Dynamics of Foreign Bank Ownership: Evidence from Hungary. Policy Research Working Papers http://dx.doi.org/10.1596/18139450-3114.

Megginson, W. L. [2005]: The Economics of Bank Privatization. Journal of Banking and Finance, Vol. 29. No. 8-9. 1931-1980. o. http://dx.doi.org/10.1016/j.jbankfin.2005.03.005.

MNB [2009]: Jelentés a pénzügyi stabilitásról, 2009. április. Magyar Nemzeti Bank, Budapest, https://www.mnb.hu/letoltes/stabjel-2009-aprilis-hu.pdf.

MNB [2012]: Jelentés a pénzügyi stabilitásról, 2012. április. Magyar Nemzeti Bank, Budapest, https://www.mnb.hu/letoltes/jelentes-penzugyi-stabilitas-201204-hu.pdf.

MNB [2014]: Átalakulóban a magyar bankrendszer. Vitaindító a magyar bankrendszerre vonatkozó konszenzusos jövőkép kialakításához. MNB-tanulmányok, különszám, http:// mek.oszk.hu/13300/13385/13385.pdf.

Nowotny, E. [2009]: Austria's role in the international financial system. Speech to representatives of official Austrian institutions. New York, április 28. http://www.bis.org/review/ r090626b.pdf.

Ongena, S.-Peydro, J. L.-van Horen, N. [2013]: Shocks Abroad, Pain at Home? Bankfirm Level Evidence on the International Transmission of Financial Shocks. Tilburg University, Center for Economic Research Discussion Paper, 2013-040.

Périlleux, A.-Vanroose, A.-D’Espallier, B. [2016]: Are Financial Cooperatives Crowded out by Commercial Banks in the Process of Financial Sector Development? Kyklos ,Vol. 69. No. 1. 108-134. o. http://dx.doi.org/10.1111/kykl.12105.

Schoenmaker, D.-Wagner, W. [2011]: The Impact of Cross-Border Banking on Financial Stability Duisenberg school of finance. Tinbergen Institute Discussion Paper, TI 11-054. DSF 18. http://papers.tinbergen.nl/11054.pdf.

Schoenmaker, D-Vernon, N. (szerk.) [2016]: European Banking Supervision. The First Eighteen Months. Bruegel Blueprint series, 25. http://bruegel.org/wp-content/ uploads/2016/06/Blueprint-XXV-web.pdf.

VÁRHEGYi Éva [1998]: A magyar banktulajdonosi szerkezet sajátos vonásai. Közgazdasági Szemle, XLV. évf., október, 906-922. o.

VÁrhegyi Éva [2002]: Bankvilág Magyarországon. Helikon Kiadó, Budapest.

VÁRHEGY Éva [2004]: A magyar bankrendszer átalakulása, működése és jellegzetes vonásai, MTA Tudományok doktora értekezés, 2004 február. 
VÁRHEGYi Éva [2011]: A magyar bankszektor szabályozása és versenyhelyzete a válságban. Megjelent: Valentiny, Pál-Kiss Ferenc László-Nagy Csongor István (szerk.): Verseny és szabályozás, 2011. 210-238. o http://econ.core.hu/file/download/vesz2011/bankszektor.pdf.

VÁrhegyi Éva [2013]: A maffiaállam bankjai. Megjelent: Magyar Bálint (szerk.): A posztkommunista maffiaállam. Noran Libro Kiadó, Budapest, 247-257. o.

VoszKa Éva [2015a]: Államosítás, privatizáció és gazdaságpolitika - a föirány széttöredezése. Közgazdasági Szemle. 62. évf. 7-8. sz. 717-748. o.

VoszKa Éva (2015b]: Államosítások: magyar fordulat vagy új európai irány? 1. rész Külgazdaság, 59. évf. 11-12. sz. 3-22. o.

World BAnk [2012]: Global Financial Development Report, 2013. Rethinking the role of the state in finance. World Bank, Washington DC.

\section{Függelék}

\section{Törvények, rendeletek, Kúria határozatok}

2011. évi CXXI. törvény az otthonvédelemmel összefüggő egyes törvények módosításáról 2012. évi CXVI. törvény a pénzügyi tranzakciós illetékről

2013. évi CXXXV. törvény a szövetkezeti hitelintézetek integrációjáról és egyes gazdasági tárgyú jogszabályok módosításáról

2013. évi CLVI. törvény a Szövetkezeti Hitelintézetek Integrációs Alapjáról

A Kúria jogegységi határozata (6/2013 PJE)

2014. évi XXXVIII. törvény a bankok elszámoltatásáról

2014. évi XL. törvény a Kúriának a pénzügyi intézmények fogyasztói kölcsönszerződéseire vonatkozó jogegységi határozatával kapcsolatos egyes kérdések rendezéséről szóló 2014 . évi XXXVIII. törvényben rögzített elszámolás szabályairól és egyes egyéb rendelkezésekről

2014. évi LXXVIII. törvény a fogyasztónak nyújtott hitelről szóló 2009. évi CLXII. törvény és egyes kapcsolódó törvények módosításáról

2014. évi XXXVII. törvény a pénzügyi közvetítőrendszer egyes szereplőinek biztonságát erősítő intézményrendszer továbbfejlesztéséről 


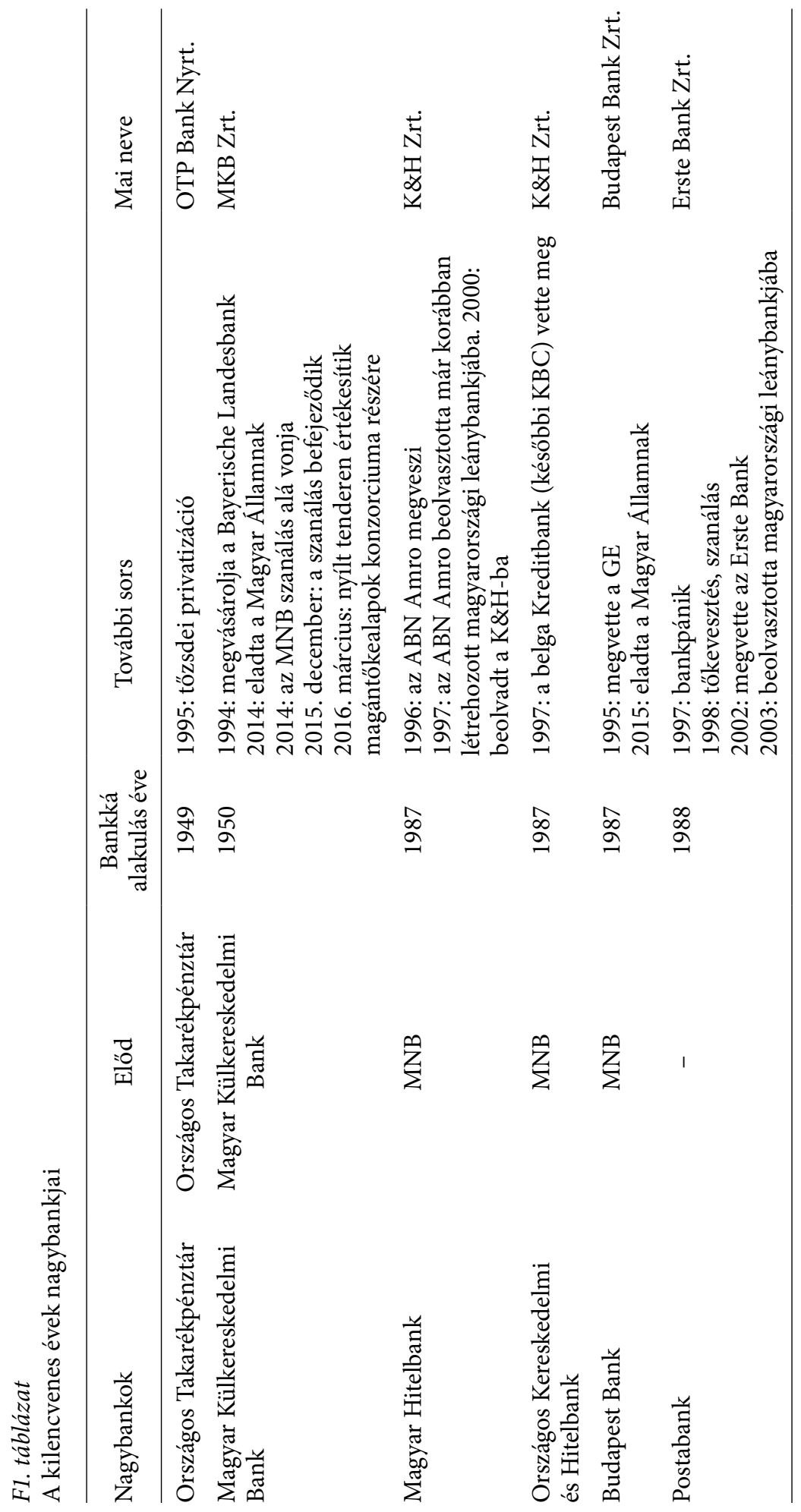


F2. táblázat

Külföldi bankok Magyarországon, 1979-2015

\begin{tabular}{|c|c|c|c|}
\hline Bank neve & $\begin{array}{l}\text { Magyarországra } \\
\text { való belépés }\end{array}$ & $\begin{array}{l}\text { Átalakulás/ } \\
\text { megszünés }\end{array}$ & Megjegyzés \\
\hline ABN Amro & 1993, zöldmezős & 2001 & $\begin{array}{l}\text { 1997: a holland anyabank } \\
\text { megvásárolja az MHB-t és beolvasztja } \\
\text { 2001: összeolvadás a K\&H bankkal }\end{array}$ \\
\hline $\begin{array}{l}\text { Aegon } \\
\text { Lakástakarékpénztár }\end{array}$ & 2013, zöldmezős & & Müködő lakás-takarékpénztár \\
\hline Allianz Bank & 2006, zöldmezős & 2010 & $\begin{array}{l}\text { 2010: a bank eladta állományát } \\
\text { az FHB banknak és megszünt }\end{array}$ \\
\hline Axa Bank & 2007, felvásárlás & 2008 & $\begin{array}{l}\text { 2008: fiókká alakult az Axa Bank } \\
\text { Europe SA-ba való beolvadással } \\
\text { 2015: az Axa a fiók állományát eladta } \\
\text { az OTP Banknak }\end{array}$ \\
\hline Banco Popolare & 2007, felvásárlás & 2013 & 2013: a Magnet Bank vásárolta meg \\
\hline Banco Primus Bank & 2008, zöldmezős & & Müködő fióktelep \\
\hline Banif Plus Bank & 2006, felvásárlás & & Müködő bank \\
\hline Bank of China & 2003, zöldmezős & & $\begin{array}{l}\text { 2014: az anyabank egy új, a leánybank } \\
\text { méretét sokszorosan meghaladó } \\
\text { fióktelepet is létrehozott } \\
\text { Müködő bank }\end{array}$ \\
\hline $\begin{array}{l}\text { Bankaustria } \\
\text { Creditanstalt (BACA) }\end{array}$ & 1990, zöldmezős & 2001 & 2001: a HVB felvásárolja \\
\hline BKD Bank & 1990, zöldmezős & 1996 & $\begin{array}{l}\text { 1996: a K\&H eladja tulajdonrészét, } \\
\text { a továbbiakban BNP-Dresdner } \\
\text { Bankként müködik }\end{array}$ \\
\hline BNP-Dresdner Bank & 1996, felvásárlás & 2001 & $\begin{array}{l}\text { 2001: a BNP kivásárolta a Dresdner } \\
\text { bankot }\end{array}$ \\
\hline BNP Paribas & 2001, felvásárlás & 2006 & $\begin{array}{l}\text { 2006: fiókká alakult } \\
\text { Müködő fiók }\end{array}$ \\
\hline Budapest Bank (GE) & 1995, privatizáció & 2015 & $\begin{array}{l}\text { 2015. június 30.: a Magyar Állam meg- } \\
\text { veszi a GE Capitaltől a Budapest Bankot }\end{array}$ \\
\hline CIB Bank & 1979, zöldmezős & & $\begin{array}{l}\text { 1997: az olasz Intesa } 95 \text { százalékos } \\
\text { tulajdont szerez } \\
\text { 2007: beolvasztja az Inter-Európa } \\
\text { Bankot, müködő bank }\end{array}$ \\
\hline
\end{tabular}


Az F2. táblázat folytatása

\begin{tabular}{|c|c|c|c|}
\hline Bank neve & $\begin{array}{l}\text { Magyarországra } \\
\text { való belépés }\end{array}$ & $\begin{array}{l}\text { Átalakulás/ } \\
\text { megszünés }\end{array}$ & Megjegyzés \\
\hline $\begin{array}{l}\text { Európai } \\
\text { Kereskedelmi Bank }\end{array}$ & 1986, zöldmezős & 2009 & $\begin{array}{l}\text { 1999: felvásárolta az Európai } \\
\text { Kereskedelmi Bankot } \\
\text { 2000: az ING lakossági üzletágát } \\
\text { 2009: fiókká alakult } \\
\text { 2015: lakossági üzletágát eladta } \\
\text { az Erste Banknak } \\
\text { Müködő fiók }\end{array}$ \\
\hline Cofidis & 2005, zöldmezős & & Müködő fióktelep \\
\hline Commerzbank & 1993, zöldmezős & & Működő bank \\
\hline Credigen Bank & 1999, zöldmezős & 2014 & $\begin{array}{l}\text { 2009: felfüggeszti tevékenységét } \\
\text { 2014: a Quaestor megvásárolja az üres } \\
\text { müködési engedélyt }\end{array}$ \\
\hline
\end{tabular}

Crédit Agricole

1992, zöldmezős

2012

Daewoo Bank

Deutsche Bank

Dresdner Bank

Erste Bank

1997, privatizáció

Európai

Kereskedelmi Bank

Fundamenta-

1997, zöldmezős

Lakáskassza

Gazprombank

Hanwha Bank

HVB Bank

1996, privatizáció

1996, felvásárlás

1993, zöldmezős

2003, zöldmezős

2006

1993, zöldmezős

1992, privatizáció
2007

2003

2011

2006

1998

2013

2005
HVB Jelzálogbank

IC Bank

Indosuez Bank

2003: a Fundamenta összeolvadt

a Lakáskasszával

Müködő lakás-takarékpénztár

2003: felvásárolja, majd beolvasztja

a Postabankot

2015: megvásárolja a Citibank

lakossági üzletágát

Müködő bank

1998: a Citibank felvásárolta

2007: átalakul befektetési társasággá

2013: az Evopro felvásárolja

2001: beolvasztja a Bankaustria-

Creditanstaltot, nevet változtat

HVB Bankra

2005: beolvad a UniCredit Bankba

A UniCredit Bank jelzálogbankja lett

2007: a Banco Popolarénak értékesítik 1996: felvásárolja a Hanwha Bank 
Az F2. táblázat folytatása

\begin{tabular}{|c|c|c|c|}
\hline Bank neve & $\begin{array}{l}\text { Magyarországra } \\
\text { való belépés }\end{array}$ & $\begin{array}{l}\text { Átalakulás/ } \\
\text { megszünés }\end{array}$ & Megjegyzés \\
\hline ING Bank & 1991, zöldmezős & 2008 & $\begin{array}{l}\text { 2008: fiókká alakult } \\
\text { Müködő fiók }\end{array}$ \\
\hline Inter-Európa Bank & 1989, privatizáció & 2006 & $\begin{array}{l}\text { 2006: beolvad a CIB-be } \\
\text { a tulajdonos felvásárlását követően }\end{array}$ \\
\hline KDB Bank & 2003, felvásárlás & & Müködő bank \\
\hline K\&H Bank & 1997, privatizáció & & $\begin{array}{l}\text { 1997: privatizációt követően } \\
\text { a belga KBC csoport tagja lett } \\
\text { 2001: Egyesül az ABN Amro } \\
\text { Magyarországgal } \\
\text { Müködő bank }\end{array}$ \\
\hline Leumi Bank & 1990, zöldmezős & 1995 & $\begin{array}{l}\text { 1995: Silver Bankká alakul, } \\
\text { majd megszünik }\end{array}$ \\
\hline $\begin{array}{l}\text { Magyar Cetelem } \\
\text { Bank }\end{array}$ & 1996, zöldmezős & & Müködő bank \\
\hline Oberbank & 2007, zöldmezős & & Müködő fióktelep \\
\hline $\begin{array}{l}\text { Magyarországi } \\
\text { Volksbank }\end{array}$ & 1993, zöldmezős & 2012 & $\begin{array}{l}\text { 2012: a Sberbank kivásárolta } \\
\text { a Volksbankot }\end{array}$ \\
\hline Opel Bank & 1996, zöldmezős & 2002 & $\begin{array}{l}\text { 2002: átalakult pénzügyi vállalkozássá } \\
\text { GM Opel néven }\end{array}$ \\
\hline Porsche Bank & 1994, zöldmezős & & Müködő bank \\
\hline Rabobank & 1997, zöldmezős & 2002 & $\begin{array}{l}\text { 2002: pénzügyi vállalkozássá alakult, } \\
\text { gyakorlatilag kivonult }\end{array}$ \\
\hline Raiffeisen Bank & 1986, privatizáció & & $\begin{array}{l}\text { 1996: a Raiffeisen International } \\
95 \text { százalékos tulajdont szerez } \\
\text { a Unicbankban } \\
\text { Müködő bank }\end{array}$ \\
\hline Sberbank & 2012, felvásárlás & & Müködő bank \\
\hline Société Générale & 1998, zöldmezős & 2002 & 2002: kivonult a piacról \\
\hline $\begin{array}{l}\text { Sopron Bank } \\
\text { Burgerland }\end{array}$ & 2003, zöldmezős & & Működő bank \\
\hline SPE Bank & 2009, zöldmezős & 2010 & $\begin{array}{l}\text { 2010: olasz alapítású a Seychelle- } \\
\text { szigeteken bejegyzett bankcsoport } \\
\text { vásárolta fel }\end{array}$ \\
\hline UniCredit Bank & 2005, felvásárlás & & $\begin{array}{l}\text { 2005: az olasz UniCredit felvásárolja } \\
\text { a német HVB-t } \\
\text { Müködő bank }\end{array}$ \\
\hline WestLB & 1992, privatizáció & 2009 & 2009: a Wallis-csoport vásárolta fel \\
\hline
\end{tabular}


F3. táblázat

Az 1995 előtt létrejött belföldi kis és közepes méretű bankok

\begin{tabular}{|c|c|c|c|}
\hline Kisbankok & Előd & $\begin{array}{l}\text { Bankká } \\
\text { alakulás }\end{array}$ & További sors \\
\hline Agrobank & $\begin{array}{l}\text { 1984, agrárbetéti } \\
\text { társaság }\end{array}$ & 1987 & $\begin{array}{l}\text { 1995: tőkevesztés, felszámolási eljárás } \\
\text { 1996: beolvadás a Mezőbankba }\end{array}$ \\
\hline $\begin{array}{l}\text { Általános } \\
\text { Értékforgalmi Bank }\end{array}$ & $\begin{array}{l}\text { 1922-ben } \\
\text { alapított bank }\end{array}$ & 1987 & 1996: felvásárolja a Gazprombank \\
\hline $\begin{array}{l}\text { Általános } \\
\text { Vállalkozási Bank }\end{array}$ & $\begin{array}{l}\text { 1985, szakosított } \\
\text { pénzintézet }\end{array}$ & 1988 & $\begin{array}{l}\text { 1992: tőkevesztés, majd a WestLB } \\
\text { felvásárolta }\end{array}$ \\
\hline Corvinbank & $\begin{array}{l}\text { 1984, Ipari } \\
\text { Innovációs Alap }\end{array}$ & 1988 & 1997: beolvadt a Konzumbankba \\
\hline Dunabank & zöldmezős & 1989 & $\begin{array}{l}\text { 1995: kártyaüzletágát megvette } \\
\text { az ING Bank, a bank többi részét } \\
\text { felszámolták }\end{array}$ \\
\hline Ibusz Bank & zöldmezős & 1991 & $\begin{array}{l}\text { 1992: megvette az Országos } \\
\text { Kereskedelmi és Hitelbank, } \\
\text { 1996: beolvasztotta }\end{array}$ \\
\hline Ingatlanbank & zöldmezős & 1989 & 1992: csőd és felszámolás \\
\hline Innofinance & $\begin{array}{l}\text { 1980, Innovációs } \\
\text { Alap }\end{array}$ & 1988 & $\begin{array}{l}\text { 1991: a Kontrax Holding Rt. } \\
60 \text { százalékos részesedést szerzett } \\
\text { a pénzintézetben } \\
\text { 1993: a Kontrax csődbe jutott } \\
\text { 1994: felszámolás }\end{array}$ \\
\hline Investbank & $\begin{array}{l}\text { 1983, Műszaki } \\
\text { Fejlesztési } \\
\text { Pénzügyi } \\
\text { Egyesülés }\end{array}$ & 1991 & 1995: beolvad a PK Bankba \\
\hline Iparbankház & $\begin{array}{l}\text { 1984, Ipari } \\
\text { Szövetkezeti } \\
\text { Fejlesztési Bank }\end{array}$ & 1990 & $\begin{array}{l}\text { 1992: csőd közeli helyzet, szanálás } \\
\text { 1996: piacról történő kivezetés }\end{array}$ \\
\hline Konzumbank & $\begin{array}{l}\text { 1986, } \\
\text { Szövetkezeti } \\
\text { Fejlesztési Bank }\end{array}$ & 1990 & $\begin{array}{l}\text { 1992: csőd közeli helyzet, szanálás } \\
\text { 1995: második konszolidáció és } \\
\text { az MFB megveszi } \\
\text { 2003: az MKB felvásárolja } \\
\text { és beolvasztja }\end{array}$ \\
\hline Kultúrbank & zöldmezős & 1990 & $\begin{array}{l}\text { 1992: csőd közeli helyzetben } \\
\text { felvásárolja a Bank Indosuez }\end{array}$ \\
\hline Magyar Takarékbank & zöldmezős & 1989 & $\begin{array}{l}\text { 1997: a DG Bank többségi tulajdont } \\
\text { szerez } \\
\text { 2003: ismét többségi magyar tulajdon }\end{array}$ \\
\hline Merkantil Bank & zöldmezős & 1988 & $\begin{array}{l}\text { 1988: a K\&H alapítja } \\
\text { 1995: az OTP felvásárolja } \\
\text { Működő bank }\end{array}$ \\
\hline
\end{tabular}


Az F3. táblázat folytatása

\begin{tabular}{|c|c|c|c|}
\hline Kisbankok & Előd & $\begin{array}{l}\text { Bankká } \\
\text { alakulás }\end{array}$ & További sors \\
\hline Mezőbank & 1986 & 1989 & $\begin{array}{l}\text { 1992: hitelkonszolidáció } \\
\text { 1996: Agrobank beolvasztása } \\
\text { 1997: Erste Bank felvásárolja }\end{array}$ \\
\hline PK Bank & 1916 & 1995 & $\begin{array}{l}\text { 1997: felvásárolja a Polgári Bankot, } \\
\text { amelyet magába olvaszt } \\
\text { 1997: } 10 \text { tagú konzorcium veszi meg } \\
\text { 2000: a Postabank felvásárolja } \\
\text { 2003: elveszti hitelintézeti } \\
\text { jogosítványát }\end{array}$ \\
\hline Polgári Bank & Ybl Bank & 1993 & $\begin{array}{l}\text { 1993: az Ybl Bank követeléseinek } \\
\text { megvásárlásával alakult } \\
\text { 1995: a BB-vel együtt GE-tulajdonba } \\
\text { kerül } \\
\text { 1997: az állam visszavásárolta, majd } \\
\text { eladta a PK Banknak, 1998: beolvadt } \\
\text { a PK Bankba }\end{array}$ \\
\hline Portfolió Bank & zöldmezős & 1990 & $\begin{array}{l}\text { Az OKHB leánybankja volt } \\
\text { Elvesztette hitelintézeti jogosítványát }\end{array}$ \\
\hline Rákóczi Bank & zöldmezős & 1992 & 1999: kivonul a piacról \\
\hline Reálbank & zöldmezős & 1989 & $\begin{array}{l}\text { 1989: Budapest Bank alapítja } \\
\text { 1993: } 50 \text { százalékban kisbefektetők } \\
\text { kezébe kerül } \\
\text { 1998: tőkevesztés után az OBA veszi át } \\
\text { 1999: felszámolás }\end{array}$ \\
\hline Ybl Bank & $\begin{array}{l}\text { 1986, Építőipari } \\
\text { Innovációs Alap }\end{array}$ & 1989 & $\begin{array}{l}\text { 1992: bankpánik, tőkevesztés } \\
\text { 1995: felszámolás során BB } \\
\text { felvásárolja és Polgári Bank néven } \\
\text { tovább működteti }\end{array}$ \\
\hline
\end{tabular}


F4. táblázat

Az integrációba tartozó és az azon kívüli takarékszövetkezeti bankok

\begin{tabular}{|c|c|c|c|}
\hline Bank & Előd & $\begin{array}{l}\text { Bankká } \\
\text { alakulás }\end{array}$ & További sors \\
\hline $\begin{array}{l}\text { Dél-Dunántúli } \\
\text { Regionális Bank } \\
\text { (DRB) }\end{array}$ & $\begin{array}{l}\text { Siklós és Vidéke } \\
\text { Takarékszövetkezet }\end{array}$ & 2009 & 2015: felszámolás \\
\hline $\begin{array}{l}\text { Észak-Magyarországi } \\
\text { Regionális Bank } \\
\text { (ÉRB) }\end{array}$ & $\begin{array}{l}\text { Takarék Szövetkezeti } \\
\text { Hitelintézet }\end{array}$ & $\begin{array}{l}2013 . \\
\text { december }\end{array}$ & 2015: felszámolás \\
\hline $\begin{array}{l}\text { Dél-Dunántúli } \\
\text { Takarék Bank (DDB) }\end{array}$ & $\begin{array}{l}\text { Dél-Dunántúli Takarék } \\
\text { Szövetkezeti Hitelintézet }\end{array}$ & $\begin{array}{l}2013 . \\
\text { december }\end{array}$ & 2015: felszámolás \\
\hline $\begin{array}{l}\text { Buda Regionális } \\
\text { Bank (BRB) }\end{array}$ & $\begin{array}{l}\text { Buda Takarék Szövetkezeti } \\
\text { Hitelintézet }\end{array}$ & $\begin{array}{l}2013 . \\
\text { december }\end{array}$ & 2015: felszámolás \\
\hline $\begin{array}{l}\text { Duna Takarék Bank } \\
\text { (DTB) }\end{array}$ & $\begin{array}{l}\text { Duna Takarékszövetkezet } \\
\text { (korábban: Halászi és } \\
\text { Vidéke és Esztergom és } \\
\text { Vidéke Takarékszövetkezet) }\end{array}$ & $\begin{array}{l}2013 . \\
\text { december }\end{array}$ & Önálló bankként müködik \\
\hline Ella Bank & $\begin{array}{l}\text { EuroDirekt } \\
\text { Takarékszövetkezet }\end{array}$ & 2004 & 2007-ben felvásárolta az Axa \\
\hline $\begin{array}{l}\text { FHB Földhitel- és } \\
\text { Jelzálogbank }\end{array}$ & & 1997 & $\begin{array}{l}\text { 2015. szeptember } 23 \text {-án } \\
\text { belépett az Integrációba }\end{array}$ \\
\hline $\begin{array}{l}\text { FHB Kereskedelmi } \\
\text { Bank }\end{array}$ & & 2007 & $\begin{array}{l}\text { 2015. szeptember } 23 \text {-án } \\
\text { belépett az Integrációba }\end{array}$ \\
\hline HBW Express Bank & HBW Takarékszövetkezet & 2008 & $\begin{array}{l}\text { 2010-től Magnet Bank } \\
\text { Müködő önálló bank }\end{array}$ \\
\hline Kinizsi Bank & $\begin{array}{l}\text { Nagyvázsony és Vidéke } \\
\text { Takarékszövetkezet }\end{array}$ & 2007 & $\begin{array}{l}\text { 2013: az integrációs törvény } \\
\text { értelmében az Integráció tagja }\end{array}$ \\
\hline Magyar Takarékbank & & 1989 & $\begin{array}{l}\text { Az Integráció jelenlegi } \\
\text { csúcsbankja }\end{array}$ \\
\hline $\begin{array}{l}\text { Mohácsi Takarék } \\
\text { Bank }\end{array}$ & $\begin{array}{l}\text { Mohács és Vidéke } \\
\text { Takarékszövetkezet }\end{array}$ & 2008 & $\begin{array}{l}\text { 2013: az integrációs törvény } \\
\text { értelmében az Integráció tagja }\end{array}$ \\
\hline $\begin{array}{l}\text { Pannon Takarék } \\
\text { Bank }\end{array}$ & $\begin{array}{l}\text { Komárom és Vidéke } \\
\text { Takarékszövetkezet }\end{array}$ & 2011 & $\begin{array}{l}\text { 2013: az integrációs törvény } \\
\text { értelmében az Integráció tagja }\end{array}$ \\
\hline Polgári Bank & $\begin{array}{l}\text { Polgár és Vidéke } \\
\text { Takarékszövetkezet }\end{array}$ & $\begin{array}{c}2013 \\
\text { december }\end{array}$ & Önálló bankként müködik \\
\hline $\begin{array}{l}\text { Széchenyi } \\
\text { Kereskedelmi Bank }\end{array}$ & SPE Bank & 2010 & 2014: felszámolás \\
\hline
\end{tabular}

